\title{
Recent advances in polymer-metallic composites for food packaging applications
}

\author{
Diogo Videira-Quintela ${ }^{\mathrm{a}}$, Olga Martin ${ }^{\mathrm{b}}$, Gemma Montalvo ${ }^{\mathrm{a}, \mathrm{c}, *}$ \\ ${ }^{a}$ Department of Analytical Chemistry, Physical Chemistry and Chemical Engineering, University of Alcalá, Ctra. Madrid-Barcelona km 33.6, 28871, Alcalá de Henares, \\ Madrid, Spain \\ ${ }^{\mathrm{b}}$ Department of Materials Science and Engineering \& Chemical Engineering, Polytechnic School, Carlos III University of Madrid, Avenida Universidad 30, 28911, \\ Leganés, Madrid, Spain \\ ${ }^{\mathrm{c}}$ Police Sciences University Research Institute, University of Alcalá, Libreros 27, 28801, Alcalá de Henares, Madrid, Spain
}

\section{A R T I C L E I N F O}

\section{Keywords:}

Food packaging

Active packaging

Polymer-metallic composites

Metallic particles

Inorganic fillers

\begin{abstract}
A B S T R A C T
Background: The use of metallic micro- and/or nanoparticles as inorganic fillers for the improvement of polymer properties is an active trend. This has led to the development of polymer-metallic composites with high potential to be applied in food packaging, due to the enhanced antimicrobial, gas barrier, light-blocking and antioxidant effect in addition to the polymer intrinsic properties. The increasing number of investigations of novel polymermetallic composites with promising potential and/or already applied as food packaging has raised concern over their efficacy, but also toxicity and environmental impact.

Scope and approach: In this review a critical evaluation of current investigations on polymer-metallic composites, as food packaging options, is assessed. This evaluation emphasizes the enhanced properties provided by the metallic fillers onto the polymer packaging itself, and indirectly in food shelf life, safety and quality. Moreover, awareness regarding the toxicity and environmental impact is also evaluated and related to the migration behaviour.

Key findings and conclusions: Without question, the addition of these type of fillers has the enormous potential to enhance the package properties and, therefore, the food shelf life. Usually, their addition is made alone or in complementation with other fillers allowing a broad spectrum of enhanced properties in the composite film. Despite the advantages, special attention must be paid to the migration form of the filler, in the ionic or the particulate form, that is related to the toxicity and environmental impact of such materials. In overall, the strengths and weaknesses are critically organized, allowing guidance decisions on the implementation of such materials in food packaging.
\end{abstract}

\section{Introduction}

Food packaging, in addition to its usual job of containing the food product, it is also responsible for ensuring the freshness, taste and nutritional value of the product, thus leading to a prolonged shelf life and safer food supply. According to AMERIPEN (American Institute for Packaging and Environment) around $20-25 \%$ of food waste can be avoided by the application of food packaging technologies, and consequently, decrease the environmental impact associated to the food waste (AMERIPEN, 2020). As a result, achieving a reduction in the food loss or waste by using novel food packaging technologies, that improve the food shelf life, safety and quality, has gained an increased interest among the academic and industry sectors.
Active food packaging is amongst these novel technologies (Realini \& Marcos, 2014). This consists in the incorporation of fillers into the food package, which in turn can interact with the food and/or the package headspace, for example, by the removal (scavenging) of gas molecules (e.g., oxygen, water vapour or carbon dioxide) or the release of antimicrobial agents (capable of controlling and inhibit the microbial growth), and thus protecting the food product (Duncan, 2011). Intelligent food packaging is another technology used, being related to the capability of monitoring the status of the food product inside the package and its surroundings by using sensors or indicators (Realini \& Marcos, 2014).

Application of inorganic micro- and/or nanomaterials has become one of the main pathways to achieve active and intelligent packaging.

\footnotetext{
* Corresponding author. Police Sciences University Research Institute, University of Alcalá, Libreros 27, 28801, Alcalá de Henares, Madrid, Spain.

E-mail addresses: diogo.videira@uah.es (D. Videira-Quintela), martinc@ing.uc3m.es (O. Martin), gemma.montalvo@uah.es (G. Montalvo).
} 
These can be applied in sachets, absorbent pads, sensors, or incorporated into the food contact package as fillers inside the polymer matrix or as coatings in the polymer surface, producing the so-called polymer microand nanocomposites (Ariyarathna, Rajakaruna, \& Karunaratne, 2017; Ogunsona, Muthuraj, Ojogbo, Valerio, \& Mekonnen, 2020; Realini \& Marcos, 2014). Various inorganic fillers such as, carbon-based materials (e.g., carbon nanotubes, graphene, etc.), clays, metal oxides (e.g., $\mathrm{ZnO}$, $\mathrm{MgO}, \mathrm{TiO}_{2}, \mathrm{CuO}, \mathrm{Al}_{2} \mathrm{O}_{3}, \mathrm{CaO}, \mathrm{SiO}_{2}$, etc.), and zero valent metallic micro-/nanoparticles (e.g., $\mathrm{Fe}, \mathrm{Ag}, \mathrm{Cu}, \mathrm{Au}, \mathrm{Pd}, \mathrm{Pt}, \mathrm{Cd}, \mathrm{Zn}$, Se, etc.), that from this point on will be referred as $\mathrm{M}_{0} \mathrm{~F}$ (i.e., metallic fillers), are largely employed to produce polymer composites to be applied in food packaging (Ariyarathna et al., 2017; Duncan, 2011; Realini \& Marcos, 2014).

With the increasing demand for packed food products with extended shelf life, much attention has been made over the years into the fabrication of polymer-metallic composites $\left(\mathrm{PM}_{0} \mathrm{C}\right)$ by the incorporation of $\mathrm{M}_{0} \mathrm{~F}$. This is due to their unique physicochemical properties that guarantee active effects, such as antimicrobial (e.g., $\mathrm{Ag}$ and $\mathrm{Cu}$ ), scavenging of gas molecules (e.g., Fe or Pd), antioxidant, (e.g., Se), but also, enhanced polymer intrinsic properties (e.g., thermal, mechanical, optical, rheological properties etc.), leading to $\mathrm{PM}_{0} \mathrm{C}$ with great future as active food packaging options (He, Deng, \& Hwang, 2019; Santos, Ingle, \& Rai, 2020).

In intelligent packaging, $\mathrm{M}_{0} \mathrm{~F}$ can also be used to develop technologies in order to monitor food quality and safety. For example, a real-time monitor device for meat spoilage was developed using a colorimetric hydrogen sulphide $\left(\mathrm{H}_{2} \mathrm{~S}\right)$ sensor based on AgNPs as indicator (Zhai et al., 2019). This sensor was centred on the ability of AgNPs to highly react to $\mathrm{H}_{2} \mathrm{~S}$ (that is considered a volatile gas produced during meat spoilage due to degradation processes of sulphur-based amino acids) to form silver sulphide $\left(\mathrm{Ag}_{2} \mathrm{~S}\right)$, that causes the colour fading of the yellow AgNPs to a blank colour.

Given the enormous progress made in nanotechnology, its spread into the fabrication of nano-based food packaging technologies was inevitable, and currently, several reviews regarding the application of nanotechnology in food packaging are available. However, their focus is somewhat general, involving a great variety of nanomaterials (Ariyarathna et al., 2017; Hoseinnejad, Jafari, \& Katouzian, 2018; Ogunsona et al., 2020), or focused on particular fillers such as metal oxides (Garcia, Shin, \& Kim, 2018), and few are fully centred in the use of zero valent $\mathrm{M}_{0} \mathrm{~F}$ as fillers in food packaging (Santos et al., 2020). Therefore, the aim of this review is to evaluate the current advances of polymer composite films with incorporated $\mathrm{M}_{0} \mathrm{~F}$ with promising potential and/or already applied as food packaging. In this review, literature that performed indirect tests (i.e., with "promising potential"; e.g., antibacterial, gas barrier, etc.) and direct food model testing (i.e., "already applied") to prove the $\mathrm{PM}_{0} \mathrm{C}$ effectiveness as food packaging, was included.

The main objectives of this review are to give the readers: (i) a critical overview of the latest $\mathrm{PM}_{0} \mathrm{C}$ technologies, (ii) the strengths and weaknesses of such systems, and (iii) the current challenges regarding their implementation in the market. Furthermore, in this work, the $\mathrm{PM}_{0} \mathrm{C}$ are classified based on the type of inorganic fillers introduced into the polymer matrix. To achieve these goals, a summary on the advantages of $\mathrm{PM}_{0} \mathrm{C}$ as food packaging is discussed, in terms of antimicrobial action, antioxidant abilities, gas barrier effects, UV-vis protection, polymer intrinsic properties (thermal, mechanical, optical, etc.) and others. Additionally, several concerns and problems regarding the application of $\mathrm{PM}_{0} \mathrm{C}$ in food packaging are discussed, with a focus on the regulations, migration, toxicity and the environmental impact. Recent literature is reviewed to present the readers the current state of the art about the use of $\mathrm{PM}_{0} \mathrm{C}$ with potential to be applied as food packaging materials.

\section{Food packaging related properties given by $M_{0} F$}

It is necessary to acknowledge the mechanisms behind the antimicrobial and gas barrier properties by which sole $\mathrm{M}_{0} \mathrm{~F}$ act, in order to understand the same active effects on $\mathrm{PM}_{0} \mathrm{C}$. The effectiveness of $\mathrm{M}_{0} \mathrm{~F}$ against a wide spectrum of microorganisms (bacteria, fungi, viruses and yeasts) has been widely reported. However the mechanisms behind their activity are varied and not fully elucidated yet (Ogunsona et al., 2020). It is of general thinking that a two-side effect occurs, being resulted from a simultaneous or asynchronous action of the direct contact of the inorganic metallic particle with the microorganism and the action of the liberated metallic ionic form.

This two-sided action causes, more specifically, antimicrobial effects that can be resumed and associated with (i) the release of the metal ions that can disrupt the ATP production and DNA replication; (ii) binding with cell membrane biomolecules leading to its disruption; (iii) physical damage by the direct contact of the particle with the microorganism, often observed by the formation of pits in the bacteria cell membrane, causing damage and/or possible penetration into the cell depending on the particle size; and (iv) the generation of reactive oxygen species to damage the DNA (Ogunsona et al., 2020; Tamayo, Azócar, Kogan, Riveros, \& Páez, 2016).

Regarding on how $\mathrm{M}_{0} \mathrm{~F}$ inside the polymer matrix can provide antimicrobial action, there is a consensus opinion that the mechanism is based on a releasing system, in which the metallic ions (due to oxidation of the metallic filler) are the main responsible for the antimicrobial activity. This is also believed to be present in all $\mathrm{PM}_{0} \mathrm{C}$ (Fig. $1 \mathrm{~A}$ and $\mathrm{C}$ ) (Ogunsona et al., 2020). However, the direct release of the $\mathrm{M}_{0} \mathrm{~F}$ in the inorganic particulate form from the polymeric matrix is also a possibility, and thus, the antimicrobial activity of migrated metallic particles in complementation with the action of the metallic ions cannot be ruled out (Fig. 1B and D). As a result, there is a strict connection of the antimicrobial activity with the migration capability of the incorporated $\mathrm{M}_{0} \mathrm{~F}$. In the end, the released ions and/or particles will provide the antimicrobial action by the distinct pathways previously described.

Improving the barrier of food packages against oxygen, water vapour and/or carbon dioxide (Fig. 1E), is incredibly important in food products in order to maintain product shelf life, quality and safety. Enhanced

\section{Metallic filler + Metallic ion $\bigcirc$ Antimicrobial activity}
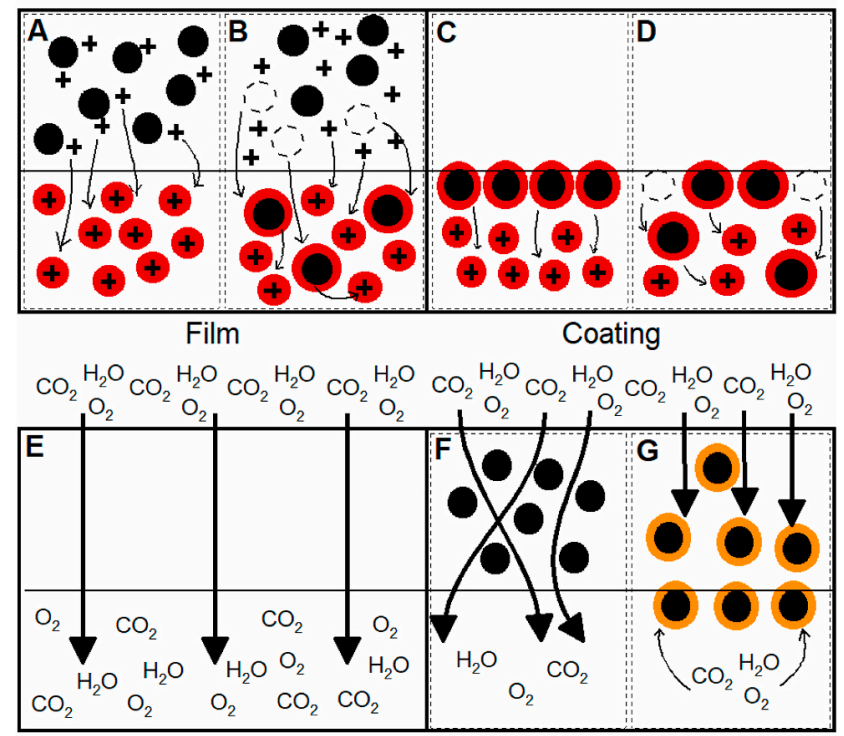

Scavenging activity

Fig. 1. Scheme regarding the possible antimicrobial mechanisms of polymermetallic composites by metallic ion release (A and $\mathrm{C}$ ) due to metallic particle oxidation and/or simultaneous metallic ion and full particle release (B and D). Moreover, schemes regarding the barrier mechanisms of polymer-metallic composites are illustrated in E, F and G. Arrows indicate the direction of the release and the empty circles represent the absence of particle. 
barrier properties of $\mathrm{PM}_{0} \mathrm{C}$ can be related to (a) the tortuous path effect provided by the incorporated inorganic fillers, as passive property, that leads to an increased path length regarding gas diffusion (i.e., the travelling of gas molecules) and thus decreasing the permeability (Fig. 1F) (Duncan, 2011); and to (b) the presence of a scavenging system (active property) able to remove the gas molecules present in the headspace and/or impede their permeability from the exterior of the package (Fig. 1G). This last mechanism depends on the type of $\mathrm{M}_{0} \mathrm{~F}$, in which iron and palladium-based fillers are commonly applied. These will be briefly discussed in Section 3 (Gaikwad, Singh, \& Lee, 2018). Moreover, induced changes in polymer intrinsic properties such as in the degree of crystallinity or reduced water uptake (hydrophobicity), will also influence the barrier properties of the $\mathrm{PM}_{0} \mathrm{C}$, with a higher degree of crystallinity and low water uptake being related to reduced gas permeability (Duncan, 2011).

As other functionalities in relation to food packaging, antioxidant and UV-vis barrier protection are also highlighted throughout the Section 3 as food packaging-related effects, induced by the incorporation of $\mathrm{M}_{0} \mathrm{~F}$. The enhancement of the polymer intrinsic properties, in terms of thermal stability, mechanical properties (tensile strength, elastic modulus, elongation at break, etc.), and others, are also typical effects provided by the incorporated $\mathrm{M}_{0} \mathrm{~F}$, allowing for more resistant food packaging films.

\section{Classification of polymer-metallic composites}

Based on the type of inorganic fillers that are introduced in the polymer matrix, in this work, the $\mathrm{PM}_{0} \mathrm{C}$ are classified as binary, ternary and quaternary, as represented in Fig. 2. Binary- $\mathrm{PM}_{0} \mathrm{C}$ (Fig. 2A), consist of a $\mathrm{M}_{0} \mathrm{~F}$ and a polymer side, and are represented as $\mathrm{M}_{0} \mathrm{~F}$-polymer (e.g., CuNPs-polymer). Ternary- $\mathrm{PM}_{0} \mathrm{C}$ are characterized by having the $\mathrm{M}_{0} \mathrm{~F}$ added separately $\left(\mathrm{M}_{0} \mathrm{~F} 1+\mathrm{F} 2\right.$-polymer, where $\mathrm{M}_{0} \mathrm{~F} 1$ is the metallic filler 1 and $\mathrm{F} 2$ is the filler 2; e.g., AgNPs $+\mathrm{SiO}_{2}$-polymer; see Fig. 2B) or physically/chemically immobilized within a second filler $\left(\mathrm{M}_{0} \mathrm{~F} 1 / \mathrm{F} 2\right.$-polymer; e.g., AgNPs/SiO 2 -polymer; see Fig. $2 \mathrm{C}$ ), into the polymer matrix. These are generally called doped structures, in which a second filler that can be organic or inorganic is doped/decorated with a $\mathrm{M}_{0} \mathrm{~F}$. These are here named as dual-side fillers (e.g., $\mathrm{AgNPs} / \mathrm{SiO}_{2}$ ). In the case of quaternary$\mathrm{PM}_{0} \mathrm{C}$, the $\mathrm{M}_{0} \mathrm{~F}$ is separately combined with two or more fillers $\left(\mathrm{M}_{0} \mathrm{~F} 1+\mathrm{F} 2+\mathrm{F} 3\right.$-polymer, where $\mathrm{F} 3$ is the filler 3 ; e.g., $\mathrm{AgNPs}+\mathrm{SiO}_{2}+\mathrm{TiO}_{2}$-polymer; see Fig. 2D), or physically/chemically immobilized, named triple-side fillers $\left(\mathrm{M}_{0} \mathrm{~F} 1 / \mathrm{F} 2 / \mathrm{F} 3\right.$-polymer; e.g., $\mathrm{AgNPs} / \mathrm{SiO}_{2} / \mathrm{TiO}_{2}$-polymer; see Fig. $2 \mathrm{E}$ ), that are then added into the polymer matrix.

\subsection{Binary polymer-metallic composites}

Polymer-silver binary composites. Silver is, without question, the most used $\mathrm{M}_{0} \mathrm{~F}$ for the fabrication of $\mathrm{PM}_{0} \mathrm{C}$. The potent broad-spectrum antimicrobial capability of silver makes it useful to be applied in the food packaging field, with also improvements in the gas barrier, UV-vis barrier, and polymer intrinsic properties, as presented in Table 1.
Melt blending of $\mathrm{M}_{0} \mathrm{~F}$ into the polymer melt is the most applied mixing strategy when using thermoplastic polymers. However, one of the main problems is the agglomeration phenomena, that often leads to defects in the polymer properties, especially when using non-polar polymers (e.g., LDPE or PP) which are immiscible and of noninteracting nature with most fillers. Thus, ensuring a proper homogeneous distribution in order to fully engage the properties of the $\mathrm{M}_{0} \mathrm{~F}$ is desired. For this, several techniques may be applied such as surface modification of the $\mathrm{M}_{0} \mathrm{~F}$ with functional groups, allowing a better interaction with the polymer matrix. Guozhou Cao et al. (Table 1) (Cao et al., 2018), synthesized surface modified AgNPs with dodecyl mercaptan to prepare AgNPs-PP binary films by melt blending. Despite the non-polar character of the PP, the surface modified AgNPs allowed a homogeneous dispersion with the agglomeration only verified at $0.7 \mathrm{wt}$ $\%$ of loading. The produced AgNPs-PP film demonstrated bacteriostatic activity against $E$. coli and $S$. aureus with inhibition rates in the order of 100 and $84.6 \%$, respectively, which was related to the $\mathrm{Ag}^{+}$ion release from the binary film.

Masterbatches of a polymer resin mixed with a $\mathrm{M}_{0} \mathrm{~F}$ are already found at the market, and it is a good alternative to provide homogeneous dispersion with a polymer melt, allowing enhanced polymer intrinsic properties, antimicrobial activity, gas barrier and UV-vis protection in comparison to their neat counterparts (Table 1) (Bumbudsanpharoke, Lee, \& Ko, 2018; Jo et al., 2018). As alternative to the mixing methods for $\mathrm{PM}_{0} \mathrm{C}$ film making, coating of polymer films is also a good solution to avoid the problems related to the inner dispersion heterogeneity. For example, Lin Li et al. (Li, Wang, \& Zhu, 2018) (Table 1) prepared a AgNPs/MPE coating onto a PE film, resulting in an enhanced (>99\%) antibacterial activity vs. $E$. coli and $S$. aureus. However, the close contact of the coating to the foodstuff may be posed as a drawback due to the related toxic effects as will be discussed in section 4 .

Nowadays, concern over the environmental impact of the conventional thermoplastics has led to an increase research over biodegradable and biobased $\mathrm{PM}_{0} \mathrm{C}$. Solution casting is the preferred mixing strategy in order to incorporate $\mathrm{M}_{0} \mathrm{~F}$ into biodegradable polymer matrices. For example, a AgNPs-PBAT binary film incorporated with AgNPs presynthesized using tocopherol (Vitamin E) as reducing agent, showed bacterial reduction of $E$. coli and L. monocytogenes after $15 \mathrm{~h}$, with improved water vapour barrier (WVB), UV-vis barrier, tensile strength and elastic modulus (Table 1) (Shankar \& Rhim, 2016). Similar food packaging related improvements are verified for other biodegradable $\mathrm{PM}_{0} \mathrm{C}$ as presented in Table 1, for PLA (Shankar, Rhim, \& Won, 2018), agar (Shankar \& Rhim, 2015), chitosan (Kadam, Momin, Palamthodi, \& Lele, 2019; Qin, Liu, Yuan, Yong, \& Liu, 2019), or blends such as gelatin/PVA (Basak, Das, Biswas, Biswas, \& Mahapatra, 2018).

An alternative approach for the fabrication of binary $\mathrm{PM}_{0} \mathrm{C}$ is by the combination of solution casting and in situ generation of the $\mathrm{M}_{0} \mathrm{~F}$. That is, the polymer is mixed with the reducing agent, and by adding the metal precursor, the in situ generation of the $\mathrm{M}_{0} \mathrm{~F}$ occurs. For example, a biodegradable AgNPs-PPC binary film was fabricated by in situ generated AgNPs using tamarind seed polysaccharide (TSP) acting as both the filler and the reducing agent (Table 1) (Devi et al., 2019a).

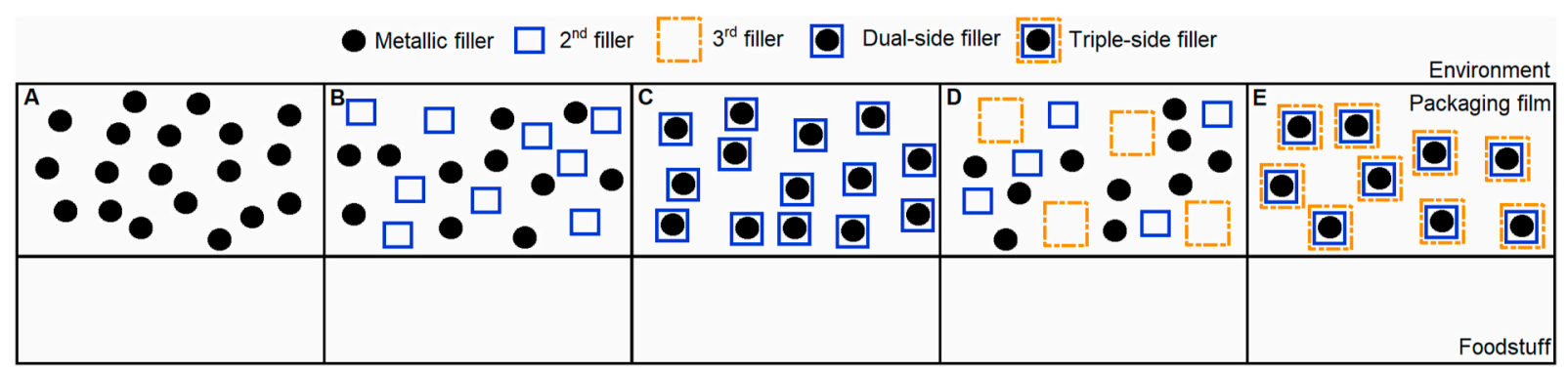

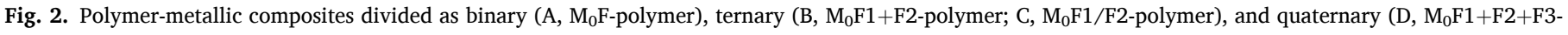
polymer; $\mathrm{E}, \mathrm{M}_{0} \mathrm{~F} 1 / \mathrm{F} 2 / \mathrm{F} 3$-polymer) composite films. $\mathrm{M}_{0} \mathrm{~F} 1$ is the metallic filler, $\mathrm{F} 2$ and $\mathrm{F} 3$ correspond to the second and third added filler. 
Table 1

Binary polymer-metallic composites with promising potential and already applied in food packaging.

\begin{tabular}{|c|c|c|c|c|c|}
\hline Filler $^{1}$ & $\begin{array}{l}\text { Added form; size; } \\
\text { loading }^{2}\end{array}$ & $\begin{array}{l}\text { Polymer matrix } \\
\text { (process) })^{3}\end{array}$ & Polymer intrinsic properties ${ }^{4}$ & Food packaging properties ${ }^{5}$ & Ref. \\
\hline \multicolumn{6}{|c|}{ Polymer-silver binary composites } \\
\hline AgNPs & $\begin{array}{l}\text { Powder; } 26-41 \mathrm{~nm} ; \\
0.1-4.0 \mathrm{wt} \%)\end{array}$ & PP (MB film) & Enhanced THS; decreased TES & Antimicrobial: $P$. aeruginosa, $S$. aureus & Oliani et al. (2017) \\
\hline AgNPs & $\begin{array}{l}\text { Colloid w/NaBH } \\
\text { 7.5-11.5 nm; } \\
0.05-0.7 \mathrm{wt} \%\end{array}$ & PP (MB film) & Enhanced THS, SM & $\begin{array}{l}\text { Antimicrobial: } \text { E. coli }(100 \%), \text { S. aureus } \\
(84.6 \%) \text {; Migration }(4 \% \mathrm{AA}, \mathrm{W}, 20 \% \mathrm{EtOH} \text {, } \\
\left.\text { and } n \text {-hexane; } 20,40,50{ }^{\circ} \mathrm{C} / 10 \mathrm{~d} ; \mu \mathrm{g} / \mathrm{cm}^{2}\right) \text { : } \\
1.8-24.5\end{array}$ & Cao et al. (2018) \\
\hline AgNPs & $\begin{array}{l}\text { AgNPs-LDPE/PP } \\
\text { masterbatches; } 30-40 \\
\mathrm{~nm} ; 3-290 \mathrm{mg} / \mathrm{kg}\end{array}$ & PP; LDPE (MB film) & $\begin{array}{l}\text { Enhanced YM, TES, EB in LDPE; } \\
\text { decreased YM, TES, EB in PP }\end{array}$ & $\begin{array}{l}\text { Antimicrobial: E. coli }(88.79-99.98 \%) \\
\text { S. aureus }(95.17-99.97 \%)\end{array}$ & Jo et al. (2018) \\
\hline AgNPs & $\begin{array}{l}\text { AgNPs-LDPE } \\
\text { masterbatch; } 20-50 \\
\mathrm{~nm} ; 3-240 \mathrm{ppm}\end{array}$ & LDPE (MB film) & $\begin{array}{l}\text { Enhanced TES, EB; decreased \%T, } \\
\text { THS, C }\end{array}$ & $\begin{array}{l}\text { Antimicrobial: E. coli, S. aureus } \\
(99.6-99.9 \%) ; \text { Barrier: WVB (14.4\%); OB } \\
(28.3 \%)\end{array}$ & $\begin{array}{l}\text { Bumbudsanpharoke } \\
\text { et al. (2018) }\end{array}$ \\
\hline AgNPs & $\begin{array}{l}\text { Powder; } 60-120 \mathrm{~nm} \\
50,100 \mathrm{ppm}\end{array}$ & PE (Coating film) & Enhanced WCA; decreased EB & $\begin{array}{l}\text { Antimicrobial: } \text { E. coli }(>99.98 \%), \text { S. aureus } \\
(99.97 \%) ; \text { Migration }\left(\mathrm{W} ; 37^{\circ} \mathrm{C} / 30 \mathrm{~d} ; \mu \mathrm{g} /\right. \\
\left.\mathrm{l}^{\circ} \mathrm{cm}^{2}\right):<0.098(100 \mathrm{ppm}),<0.075(50 \\
\mathrm{ppm}) \text { at } 30 \mathrm{~d}\end{array}$ & $\begin{array}{l}\mathrm{Li}, \mathrm{Li} \text {, Zhang, Yuan, and } \\
\text { Qin (2018) }\end{array}$ \\
\hline AgNPs & $\begin{array}{l}\text { Colloid w/tocopherol; } \\
10-50 \mathrm{~nm} ; 0.25 \mathrm{wt} \%\end{array}$ & PBAT (SC film) & $\begin{array}{l}\text { Enhanced TES, EM, WCA; } \\
\text { decreased EB }\end{array}$ & $\begin{array}{l}\text { Antimicrobial: } E \text {. coli }\left(\sim 60-80 \%^{*} \text { at } 15 \mathrm{~h}\right) \text {, } \\
\text { L. monocytogenes }\left(\sim 40-60 \%^{*} \text { at } 15 \mathrm{~h}\right) \text {; } \\
\text { Barrier: WVB }\left(\sim 18 \%^{*}\right) \text {; UV-vis barrier }\end{array}$ & $\begin{array}{l}\text { Shankar and Rhim } \\
\text { (2016) }\end{array}$ \\
\hline AgNPs & $\begin{array}{l}\text { Colloid w/lignin; } \\
<100 \mathrm{~nm} ; 0.1,0.5 \mathrm{wt} \\
\%\end{array}$ & PLA (SC film) & $\begin{array}{l}\text { Enhanced TES, EM, THS; } \\
\text { decreased \% }\end{array}$ & $\begin{array}{l}\text { Antimicrobial: E. coli, L. monocytogenes } \\
(\sim 100 \% * \text { at } 15 \mathrm{~h}) \text {; Barrier: } \operatorname{WVB}\left(\sim 17 \%^{*}\right) \text {; } \\
\text { UV-vis barrier }\end{array}$ & Shankar et al. (2018) \\
\hline AgNPs & $\begin{array}{l}\text { Colloid w/amino } \\
\text { acids; } 10-20 \mathrm{~nm}\end{array}$ & Agar (SC film) & $\begin{array}{l}\text { Enhanced EB, MC; decreased \%T, } \\
\text { TES, EM, THS, WCA }\end{array}$ & $\begin{array}{l}\text { Antimicrobial: } \text { E. coli }(\sim 78-90 \% * \text { at } 15 \mathrm{~h}) \text {, } \\
\text { L. monocytogenes }(\sim 50-80 \% * \text { at } 15 \mathrm{~h}) \text {; } \\
\text { Barrier: WVB }(\sim 4-14 \% * \text { increase); UV-vis } \\
\text { barrier }\end{array}$ & $\begin{array}{l}\text { Shankar and Rhim } \\
\text { (2015) }\end{array}$ \\
\hline AgNPs & $\begin{array}{l}\text { Colloid w/plant } \\
\text { extract; } 2-15 \mathrm{~nm} \text {; } \\
0.1-0.3 \% \mathrm{w} / \mathrm{v}\end{array}$ & Chitosan (SC film) & $\begin{array}{l}\text { Enhanced TES, EB, THS, WS; } \\
\text { decreased MC. }\end{array}$ & $\begin{array}{l}\text { Antimicrobial: } \text { E. coli, } P \text {. aeruginosa, } \\
\text { B. subtilis, } S \text {. aureus }\left(\sim 45-60 \%{ }^{*}\right) \text {; Barrier: } \\
\text { WVB (15\%); Migration (PB pH } 5.5 \text { and } 6.8 \text {; } \\
25^{\circ} \mathrm{C} / 10 \mathrm{~d} \text {; ppm): } 0.3-1.5^{*}\end{array}$ & Kadam et al. (2019) \\
\hline AgNPs & $\begin{array}{l}\text { Powder; } 60-120 \mathrm{~nm} ; \\
2 \mathrm{wt} \%\end{array}$ & Chitosan (SC film) & $\begin{array}{l}\text { Enhanced TES; decreased EB, MC, } \\
\text { WS }\end{array}$ & $\begin{array}{l}\text { Antimicrobial: E. coli, Salmonella, S. aureus, } \\
\text { L. monocytogenes; Barrier: WVB ( } \sim 8-16 \% \\
\text { *); UV-vis barrier; Antioxidant properties } \\
\text { (due to added PCE); Intelligent Packaging: } \\
\text { pH sensitive colour changes (due to added } \\
\text { PCE) }\end{array}$ & Qin et al. (2019) \\
\hline AgNPs & $\begin{array}{l}\text { Colloid w/plant } \\
\text { extract; } 15-80 \mathrm{~nm}\end{array}$ & Gelatin/PVA (SC film) & - & Antimicrobial: $E$. coli, $S$. aureus & Basak et al. (2018) \\
\hline AgNPs & $\begin{array}{l}\text { In situ w/TSP; 44-86 } \\
\mathrm{nm} ; 1.0-5.0 \mathrm{mM}\end{array}$ & PPC (SC film) & $\begin{array}{l}\text { Enhanced TM, TES, THS; } \\
\text { decreased EB }\end{array}$ & $\begin{array}{l}\text { Antimicrobial: P. aeruginosa, E. coli, } \\
\text { B. lichenformis, S. aureus }\end{array}$ & Devi et al. (2019a) \\
\hline AgNPs & $\begin{array}{l}\text { In-situ w/UV } \\
\text { radiation; 16-797 } \\
\mathrm{mg} / \mathrm{kg}(0.006-0.32 \\
\mathrm{wt} \%)\end{array}$ & Starch/PVA (SC film) & $\begin{array}{l}\text { Enhanced EM and TES }(0.006 \text {, } \\
0.06 \mathrm{wt} \%), \mathrm{EB}(0.16,0.32 \mathrm{wt} \%) \text {; } \\
\text { decreased EB }(0.006,0.06 \mathrm{wt} \%) \text {, } \\
\text { EM and TES }(0.16,0.32 \mathrm{wt} \%) \text {, } \\
\text { THS, MC, T }\end{array}$ & $\begin{array}{l}\text { Antimicrobial: } L \text {. innocua }(>80 \% *) \text {, E. coli, } \\
\text { A. niger, } P \text {. expansum }\left(>99 \% \%^{*}\right) \text {; Barrier: } \\
\text { WVB }(\sim 10-25 \% *) \text {; Migration }\left(20^{\circ} \mathrm{C} / 7 \mathrm{~d}\right) \text { : } \\
3 \% \text { AA: } 100 \% \text { at } 1 \mathrm{~h} ; 10,20,50 \% \text { EtOH: } \\
100 \% \text { at } 4-10 \text { h; oleic acid: } 50-78 \%\end{array}$ & Cano et al. (2016) \\
\hline AgNPs & $\begin{array}{l}\text { In situ w/pullulan; } 7 \\
\mathrm{mM}\end{array}$ & $\begin{array}{l}\text { Pullulan; Pullulan// } \\
\text { Pectin (SC film) }\end{array}$ & $\begin{array}{l}\text { Enhanced MC, WCA, EB; } \\
\text { decreased \%T, TES, EM }\end{array}$ & $\begin{array}{l}\text { Antimicrobial: } E \text {. coli, } \text { L. monocytogenes, } \\
\text { S. typhimurium, } S \text {. aureus, B. cereus }(100 \% *)\end{array}$ & Lee et al. (2019) \\
\hline AgNPs & $\begin{array}{l}\text { In situ w/gelatin; } \\
45-180 \mathrm{mM}(0.2-0.8 \\
\text { wt } \%)\end{array}$ & Gelatin (SC film) & $\begin{array}{l}\text { Enhanced THS; decreased TES, } \\
\text { EB, WS }\end{array}$ & $\begin{array}{l}\text { Antimicrobial: } S \text {. aureus, E. coli; Barrier: } \\
\text { WVB ( } 12.7 \% \text { absence of TA; } 13 \% \text { in the } \\
\text { presence of TA) }\end{array}$ & Menezes et al. (2019) \\
\hline AgNPs & $\begin{array}{l}\text { In situ w/banana } \\
\text { powder; 100-200 nm; } \\
1.0 \mathrm{mM}\end{array}$ & Agar (SC film) & $\begin{array}{l}\text { Enhanced EB; decreased TES, EM, } \\
\text { MC, WCA, \%T. }\end{array}$ & $\begin{array}{l}\text { Antimicrobial: } E \text {. coli }(\sim 100 \% * \text { at } 15 \mathrm{~h}) \text {, } \\
\text { L. monocytogenes }(\sim 57 \% * \text { at } 15 \mathrm{~h}) \text {; UV-vis } \\
\text { barrier; Antioxidant properties. }\end{array}$ & Orsuwan et al. (2016) \\
\hline AgNPs & $\begin{array}{l}\text { In situ w/starch- } \\
\text { maltose; } 13-20 \mathrm{~nm} \text {; } \\
143 \mathrm{ppm}\end{array}$ & Starch (SC film) & $\begin{array}{l}\text { Enhanced MC, TES, EM; } \\
\text { decreased T }\end{array}$ & $\begin{array}{l}\text { Antimicrobial: Salmonella spp., E. coli, } \\
\text { S. aureus, Penicillium spp.; Barrier: WVB } \\
(\sim 17-50 \% *) \text {; UV-vis barrier }\end{array}$ & Ortega et al. (2019) \\
\hline AgNPs & $\begin{array}{l}\text { In situ w/lignin; }<500 \\
\mathrm{~nm} ; 0.5-2.0 \mathrm{wt} \%\end{array}$ & Agar (SC film) & $\begin{array}{l}\text { Enhanced THS, TES, EM, WCA; } \\
\text { decreased \%T, WS, swelling }\end{array}$ & $\begin{array}{l}\text { Antimicrobial: } E \text {. coli }(\sim 100 \% * \text { at } 6 \mathrm{~h}) \text {, } \\
\text { L. monocytogenes }(\sim 100 \% * \text { at } 12 \mathrm{~h}) \text {; Barrier: } \\
\text { WVB }(\sim 8-16 \% *) \text {; UV-vis barrier }\end{array}$ & $\begin{array}{l}\text { Shankar and Rhim } \\
\text { (2017) }\end{array}$ \\
\hline AgNPs & $\begin{array}{l}\text { Colloid; } 10-20 \mathrm{~nm} \text {; } \\
0.5,1.0 \mathrm{wt} \%\end{array}$ & LDPE (MB film) & Decreased TES, YM, EB & $\begin{array}{l}\text { Food Application (chicken breast fillets; } \\
4{ }^{\circ} \mathrm{C} / 12 \mathrm{~d} \text { ): reduction in psychotropic } \\
\text { bacteria }\left(\sim 17 \%^{*}\right) \text {; enhanced oxidative } \\
\text { stability }\end{array}$ & $\begin{array}{l}\text { Azlin-Hasim et al. } \\
\text { (2015) }\end{array}$ \\
\hline AgNPs & $\begin{array}{l}\text { Colloid w/plant } \\
\text { extract; } 25-45 \mathrm{~nm} \text {; } \\
0.05,1.0 \mathrm{wt} \%)\end{array}$ & $\begin{array}{l}\text { Chitosan/Gelatin (SC } \\
\text { film) }\end{array}$ & Enhanced EB; decreased TES & $\begin{array}{l}\text { UV-vis barrier; Food Application (red } \\
\left.\text { grape; } 37^{\circ} \mathrm{C} / 25 \mathrm{~d}\right) \text { : decreased mildew, } \\
\text { putridity and bad odour; prolonged shelf life } \\
\text { to } 14 \mathrm{~d}(0.05 \mathrm{wt} \%) \text { and } 18 \mathrm{~d}(0.1 \text { wt } \%) \text { vs. } \\
\text { control }(<14 \mathrm{~d} \text { in neat PE) }\end{array}$ & Kumar et al. (2018) \\
\hline AgNPs & $<20 \mathrm{~nm} ; 1.0-3.0 \mathrm{wt} \%$ & PE (MB film) & - & $\begin{array}{l}\text { Food Application (pistachio, walnut, } \\
\text { almond, hazelnut; RT/ } 24 \mathrm{~m} \text { ): inhibited } \\
\text { growth of TBC, coliform and moulds; } \\
\text { reduced peroxide and aflatoxin values; }\end{array}$ & Tavakoli et al. (2017) \\
\hline
\end{tabular}


Table 1 (continued)

\begin{tabular}{|c|c|c|c|c|c|}
\hline Filler $^{1}$ & $\begin{array}{l}\text { Added form; size; } \\
\text { loading }^{2}\end{array}$ & $\begin{array}{l}\text { Polymer matrix } \\
\text { (process) }^{3}\end{array}$ & Polymer intrinsic properties ${ }^{4}$ & Food packaging properties 5 & Ref. \\
\hline & & & & $\begin{array}{l}\text { prolonged shelf life to } 20 \mathrm{~m} \text { (pistachios), } \\
19 \mathrm{~m} \text { (almonds, } 18 \mathrm{~m} \text { (hazelnuts), and } 18 \mathrm{~m} \\
\text { (walnut) vs. control (13m) }\end{array}$ & \\
\hline \multicolumn{6}{|c|}{ Polymer-copper binary composites } \\
\hline CuNPs & $\begin{array}{l}\text { In situ } \mathrm{w} / \mathrm{NaBH}_{4} \\
53.28 \pm 15.54 \mathrm{~nm} \\
0.5-5.0 \mathrm{wt} \%\end{array}$ & HPMC (SC film) & Enhanced TES, EB & $\begin{array}{l}\text { Antimicrobial: } S \text {. epidermidis, Streptococus } \\
\text { A, S. aureus, B. cereus; Barrier: WVB } \\
\left(\sim 41-60 \%{ }^{*}\right) \text {; Food Application (minced } \\
\left.\text { meat, } 4{ }^{\circ} \mathrm{C} / 15 \mathrm{~d}\right) \text { : inhibited growth of TBC } \\
\text { vs. control }\end{array}$ & $\begin{array}{l}\text { Ebrahimiasl and } \\
\text { Rajabpour (2015) }\end{array}$ \\
\hline CuNPs & $\begin{array}{l}\text { In situ w/TNP; 47-68 } \\
\mathrm{nm} ; 1-250 \mathrm{mM}\end{array}$ & PPC (SC film) & $\begin{array}{l}\text { Enhanced THS, EM, TES; } \\
\text { decreased EB }\end{array}$ & $\begin{array}{l}\text { Antimicrobial: } E \text {. coli, } P . \text { aeruginosa, } \\
\text { B. licheniformis, } S . \text { aureus }\end{array}$ & Devi et al. (2019b) \\
\hline CuNPs & $\begin{array}{l}\text { Powder; } 50 \mathrm{~nm} \text {; } \\
0.25-1.0 \mathrm{wt} \%\end{array}$ & PP (MB film) & $\begin{array}{l}\text { Enhanced T, EB, THS; decreased } \\
\text { TES }\end{array}$ & $\begin{array}{l}\text { Antimicrobial: E. coli, S. aureus, Shigella } \\
\text { castellani, B. subtilis; Migration ( } 3 \% \text { AA): } \\
6.01-7.71 \%\left(20{ }^{\circ} \mathrm{C} / 40 \mathrm{~d}\right) ; 21.6-35.1 \% \\
\left(40{ }^{\circ} \mathrm{C} / 35 \mathrm{~d}\right) ; 27.3-53.3 \%\left(55^{\circ} \mathrm{C} / 15 \mathrm{~d}\right) ; \\
24.8-53.1 \%\left(70{ }^{\circ} \mathrm{C} / 48 \mathrm{~h}\right) ; 6.01-24.8(0.25 \\
\text { wt } \%) ; 6.4-35.6 \%(0.5 \text { wt } \%) ; 7.75-53.1 \% \\
(1.0 \text { wt } \%)\end{array}$ & Jiang et al. (2019) \\
\hline CuNPs & $\begin{array}{l}\text { Powder; } 50 \mathrm{~nm} ; 0.5-3 \\
\text { wt. } \%\end{array}$ & LDPE (SC film) & Enhanced THS, TES, EB & 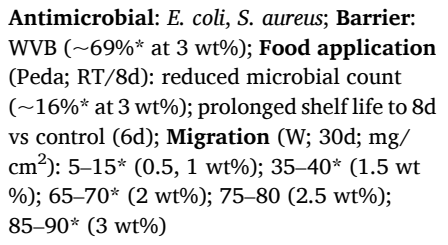 & Lomate et al. (2018) \\
\hline CuNPs & $\begin{array}{l}\text { In situ w/leaf extract; } \\
10-60 \mathrm{~nm} ; 5-250 \mathrm{mM}\end{array}$ & Cellulose (SC film) & Decreased THS & Antimicrobial: $E$. coli & $\begin{array}{l}\text { Muthulakshmi et al. } \\
\text { (2017) }\end{array}$ \\
\hline $\begin{array}{l}\text { CuNPs; } \\
\text { CuMPs }\end{array}$ & $\begin{array}{l}\text { Powder; } 10 \mathrm{~nm} ; 45 \\
\mu \mathrm{m} ; 1.0,5.0 \mathrm{vol} \%\end{array}$ & $\begin{array}{l}\text { PP; PA6; PPC18; HDPE } \\
\text { (MB film) }\end{array}$ & Enhanced EM & $\begin{array}{l}\text { Antimicrobial: } S \text {. aureus, } P \text {. aeruginosa; } \\
\text { Migration }\left(\mathrm{W} ; \mu \mathrm{g} /\left(\mathrm{mL}^{*} \mathrm{~cm}^{2}\right)\right) \text { : } \sim 2.5-3.0^{*} \\
\text { w/PA6; } \sim 1.75-2.0^{*} \text { w/PPC18; } \sim 1.25-1.5^{*} \\
\text { w/PP; } \sim 0.75-1.0 \text { w/HDPE }\end{array}$ & Palza et al. (2015) \\
\hline \multicolumn{6}{|c|}{ Polymer-other metallic binary composites } \\
\hline PdNPs & $1.04 \mathrm{~nm}$ & PET (Coating film) & - & $\begin{array}{l}\text { Food application (cooked cured ham; } 4{ }^{\circ} \mathrm{C} / \\
21 \mathrm{~d} \text { in normal atmosphere }(\sim 20.95 \mathrm{vol} \% \\
\mathrm{O}_{2} \text { ) or w/MAP ( } 2 \text { vol } \% \mathrm{O}_{2}, 5 \mathrm{vol} \% \mathrm{H}_{2}, 93 \mathrm{vol} \\
\left.\% \mathrm{~N}_{2}\right): 100 \% \text { scavenging at } 35 \mathrm{~min} \text { of } 2 \mathrm{vol} \% \\
(\mathrm{MAP} \text { experiment); effective prevention in } \\
\text { the decolorization of ham; prolonged shelf- } \\
\text { life of } 21 \mathrm{~d} \text { vs. control }\end{array}$ & Hutter et al. (2016) \\
\hline PdNPs & $\begin{array}{l}\text { Powder; }<25 \mathrm{~nm} ; 1 \mathrm{wt} \\
\%\end{array}$ & $\begin{array}{l}\text { PHB; PCL } \\
\text { (Electrospinning } \\
\text { compressed film) }\end{array}$ & Enhanced THS & $\begin{array}{l}\text { Barrier: WVB ( } \sim 98.7 \% \text { for paper/PHB film/ } \\
\text { PCL-PdNPs film); OB }(\sim 81 \% \text { at } 3000 \mathrm{~min} \text {, } \\
50 \% \text { RH for paper/PHB fibers/PCL-PdNP } \\
\text { and paper/PHB-PdNPs fiber/PCL-PdNPs } \\
\text { film; } \sim 100 \% \text { at } 1250 \mathrm{~min}, 50 \% \text { RH for PCL- } \\
\text { PdNPs) }\end{array}$ & Cherpinski et al. (2018) \\
\hline PdNPs & $\begin{array}{l}\text { Powder; }<25 \mathrm{~nm} ; 1 \mathrm{wt} \\
\%\end{array}$ & $\begin{array}{l}\text { PHB (Electrospinning } \\
\text { compressed film) }\end{array}$ & Enhanced THS, TES, and EM & Barrier: OB ( $30 \%$ at $16.5 \mathrm{~h}, 100 \% \mathrm{RH})$ & Cherpinski et al. (2019) \\
\hline Ag-CuNPs & $\begin{array}{l}\text { Powder; }<100 \mathrm{~nm} ; \\
2.0,4.0 \mathrm{wt} \%\end{array}$ & PLA/PEG (MB film) & Enhanced C & $\begin{array}{l}\text { Antimicrobial: } S \text {. typhimurium, } \\
\text { L. monocytogenes, C. jejuni (all } \sim 25-64 \% * \\
\text { for } \mathrm{Ag}-\mathrm{Cu} / \mathrm{PLA}, \sim 77-100 \% * \text { for } \mathrm{Ag}-\mathrm{Cu} / \\
\mathrm{CEO} / \mathrm{PLA}) \text {; Barrier: WVB }\left(\sim 41 \% \%^{*} \text { at } 4 \mathrm{wt}\right. \\
\%), \mathrm{OB}(\sim 39 \% * \text { at } 4 \mathrm{wt} \%) \text {; UV-vis barrier; } \\
\text { Food application (contaminated chicken } \\
\left.\text { meat; } 4{ }^{\circ} \mathrm{C} / 21 \mathrm{~d}\right) \text { : decreased microbial count; } \\
\text { below LOD at the } 21 \text { st day for } S \text {. typhimurium } \\
\text { and } C \text {. jejuni }\end{array}$ & $\begin{array}{l}\text { Ahmed, Arfat, et al. } \\
\text { (2018) }\end{array}$ \\
\hline Ag-CuNPs & $\begin{array}{l}\text { Powder; }<100 \mathrm{~nm} ; \\
0.5-4.0 \mathrm{wt} \%\end{array}$ & LLDPE (MB film) & Enhanced C & $\begin{array}{l}\text { Antimicrobial: } S \text {. typhimurium, } \\
\text { L. monocytogenes, C. jejuni (all } \sim 60-100 \% *) \text {; } \\
\text { Barrier: WVB }\left(\sim 75 \% \%^{*} \text { at } 4 \mathrm{wt} \%\right), \mathrm{OB} \\
(\sim 31 \% * \text { at } 4 \mathrm{wt} \%) \text {; UV-vis barrier; Food } \\
\text { application (contaminated chicken meat; } \\
\left.4^{\circ} \mathrm{C} / 21 \mathrm{~d}\right) \text { : decreased microbial count; } \\
\text { below LOD at the } 14 \mathrm{~d} \text { and } 7 \mathrm{~d} \text { for } \\
S . \text { typhimurium and } C \text {. jejuni; }>70 \% \text { at } 21 \mathrm{~d} \\
\text { for } L \text {. monocytogenes }\end{array}$ & $\begin{array}{l}\text { Ahmed, Mulla, et al. } \\
\text { (2018) }\end{array}$ \\
\hline Ag-CuNPs & $\begin{array}{l}\text { Powder, }<100 \mathrm{~nm} \text {; } \\
0.5-2.0 \mathrm{wt} \%\end{array}$ & Guar gum (SC film) & $\begin{array}{l}\text { Enhanced TES, THS, thermal } \\
\text { conductivity, thermal diffusivity; } \\
\text { decreased EB, T }\end{array}$ & $\begin{array}{l}\text { Antimicrobial: } S . \text { typhimurium }(\sim 20-52 \% \\
*), \text { L. monocytogenes }(\sim 10-36 \% *) \text {; Barrier: } \\
\text { OB }(56.1 \% \text { at } 2.0 \text { wt } \%) \text {; UV-vis barrier }\end{array}$ & $\begin{array}{l}\text { Arfat, Ejaz, Jacob, and } \\
\text { Ahmed (2017) }\end{array}$ \\
\hline Ag-CuNPs & $\begin{array}{l}\text { Powder, }<100 \mathrm{~nm} \text {; } \\
0.5-4.0 \mathrm{wt} \%\end{array}$ & Agar (SC film) & $\begin{array}{l}\text { Enhanced TES, THS, C; decreased } \\
\text { EB, T }\end{array}$ & $\begin{array}{l}\text { Antimicrobial }{ }^{\mathrm{e}} \text { : S. typhimurium }(\sim 34- \\
7-66.4 \% *), \text { L. monocytogenes }(\sim 21-54.7 \% \\
\text { *); Barrier: OB ( } 54.01 \% \text { at } 4 \mathrm{wt} \%) ; \mathrm{UV}-\mathrm{vis} \\
\text { barrier }\end{array}$ & $\begin{array}{l}\text { Arfat, Ahmed, and } \\
\text { Jacob (2017) }\end{array}$ \\
\hline
\end{tabular}


Table 1 (continued)

\begin{tabular}{|c|c|c|c|c|c|}
\hline Filler $^{1}$ & $\begin{array}{l}\text { Added form; size; } \\
\text { loading }^{2}\end{array}$ & $\begin{array}{l}\text { Polymer matrix } \\
\text { (process) }^{3}\end{array}$ & Polymer intrinsic properties ${ }^{4}$ & Food packaging properties 5 & Ref. \\
\hline SeNPs & $\begin{array}{l}\text { Colloid w/AA; 50-60 } \\
\mathrm{nm} ; 10 \mathrm{wt} \%\end{array}$ & $\begin{array}{l}\text { PET-PUR-LDPE } \\
\text { multilayer film (Solution } \\
\text { mixing w/PUR adhesive) }\end{array}$ & - & $\begin{array}{l}\text { Antioxidant properties ( } \sim 69 \% * \max \text {. } \\
\text { antioxidant capacity); Migration }(50 \% \\
\left.\text { EtOH, } 3 \% \text { AA, hazelnuts; } 60^{\circ} \mathrm{C} / 10 \mathrm{~d}\right):<\text { LOD }\end{array}$ & Vera et al. (2016) \\
\hline AuNPs & $\begin{array}{l}\text { Colloid } w / \text { sodium } \\
\text { citrate; }<3 \mu \mathrm{m} \text { in film; } \\
0.85 \mathrm{wt} \%)\end{array}$ & PVA (SC film) & $\begin{array}{l}\text { Enhanced TES, YM, THS; } \\
\text { decreased EB, WS }\end{array}$ & $\begin{array}{l}\text { Antimicrobial: } E \text {. coli; Barrier: WVB } \\
(\sim 10 \% *) \text {; Food application (bananas, RT/ } \\
5 \text { d): enhanced preservation up to } 5 \text { d vs } \\
\text { control }\end{array}$ & $\begin{array}{l}\text { Chowdhury et al. } \\
\text { (2020) }\end{array}$ \\
\hline AuNPs & $\begin{array}{l}\text { Colloid w/ } \mathrm{NaBH}_{4} ; 5.5 \\
\pm 1.4 \mathrm{~nm} ; 2.5,5 \% \mathrm{v} / \mathrm{v}\end{array}$ & Starch (SC film) & $\begin{array}{l}\text { Enhanced TES; decreased EB, WS, } \\
\% \mathrm{~T}\end{array}$ & $\begin{array}{l}\text { Antimicrobial: } S \text {. aureus }(98 \%), \text { E. coli } \\
(99.9 \%) \text {; Barrier: WVB }(\sim 14-18 \% *) \text {, OB } \\
\text { and } \mathrm{CO}_{2} \mathrm{~B} \text { below LOD; UV-vis barrier }\end{array}$ & Pagno et al. (2015) \\
\hline
\end{tabular}

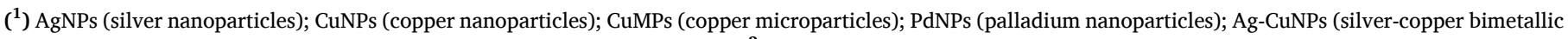

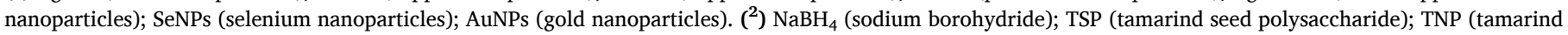

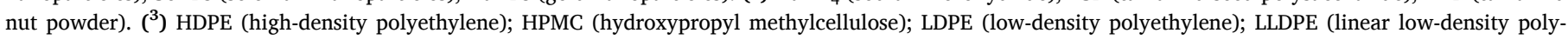

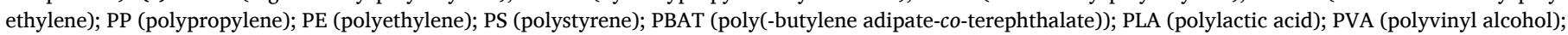

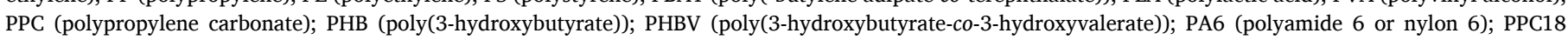

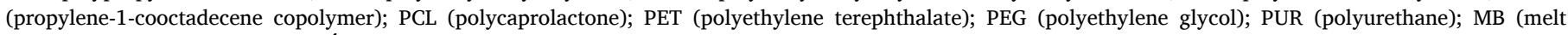

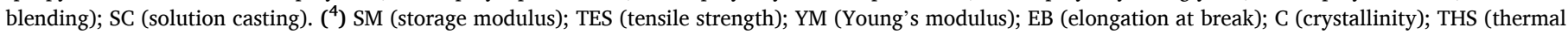

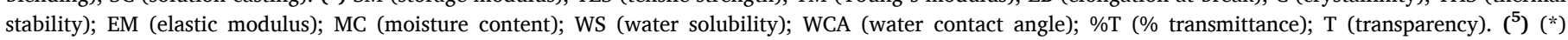

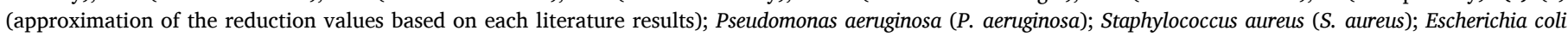

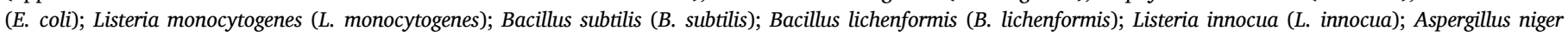

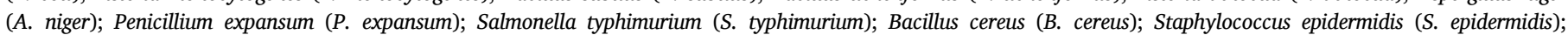

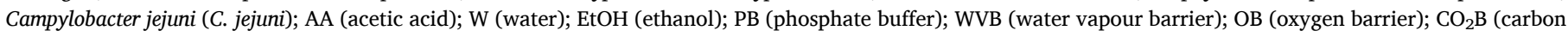

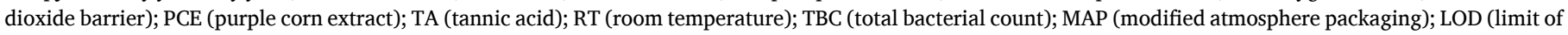
detection).

Antimicrobial activity against E. coli, P. aeruginosa, B. licheniformis and $S$. aureus was verified, accompanied with enhanced tensile strength, thermal stability and storage modulus. Several other studies adopted this strategy as presented in Table 1 for in situ generated $\mathrm{M}_{0} \mathrm{~F}$ in a starch/PVA (Cano, Cháfer, Chiralt, \& González-Martínez, 2016), pullulan and pullulan/pectin (Lee, Jeong, \& Kanmani, 2019), gelatin (Menezes et al., 2019), agar (Orsuwan, Shankar, Wang, Sothornvit, \& Rhim, 2016; Shankar \& Rhim, 2017), and starch (Ortega, García, \& Arce, 2019) films.

Polymer-silver binary composite films have also been tested with real food systems to determine their effectiveness on food shelf life extension. For instance, a AgNPs-LDPE film was tested to serve as potential food packaging option for chicken breast fillets (Table 1) (Azlin-Hasim, Cruz-Romero, Morris, Cummins, \& Kerry, 2015), resulting in growth inhibition of psychotropic bacteria accompanied with an enhanced oxidative stability compared to a LDPE control film. Other studies of AgNPs-polymer binary films (Table 1 ) resulted in the shelf life extension of red grapes (18 days vs. $<14$ days in control film) and dry fruits (18-20 months vs. 13 months in control film) (Kumar, Shukla, Baul, Mitra, \& Halder, 2018; Tavakoli, Rastegar, Taherian, Samadi, \& Rostami, 2017).

Polymer-copper binary composites. Copper-based fillers have long been used to reinforce polymer matrices (Tamayo et al., 2016). It is an economically cheaper metal as compared to others like gold, silver, or platinum, making it very promising for industrial-scale applications. The incorporation of copper-based fillers has leaded to the generation of $\mathrm{PM}_{0} \mathrm{C}$ with enhanced properties, suitable to be applied as food packaging options, as presented in Table 1.

As examples of copper-based binary films applied in real food packaging, a CuNPs-LDPE film (Table 1) was used to store Peda (Indian sweet dairy product) (Lomate, Dandi, \& Mishra, 2018). The CuNPs-LDPE film exhibited antimicrobial activity that was associated to the release of copper ions, allowing the shelf life extension of Peda up to 8 days in comparison with the control LDPE film, where Peda started to degrade at the 6th day. This film was prepared by mixing pre-synthesized CuNPs using a microwave assisted method with the LDPE polymer solution. In another study, a CuNPs-HPMC binary film showed potential for food packaging due to the increased antimicrobial activity, gas barrier properties, and the inhibition of the total bacteria count in a packed sample of minced meat (Table 1) (Ebrahimiasl \&

\section{Rajabpour, 2015).}

Polymer-other metallic binary composites. Metal-based scavengers inside a polymeric matrix can act both as physical (through the tortuous path effect) and active barrier (through chemical reactions) to scavenge the permeating and inner package oxygen, protecting the food against oxygen-induced problems, and thus extending the shelf life. For example, in a melt blended PP composite film filled with $\sim 20 \mathrm{wt} \%$ of an iron-based oxygen scavenger powder (SHELFPLUS ${ }^{\circledR}$ O2 2710 with an oxygen absorption capacity of $44 \mathrm{mg} \mathrm{O}_{2}$ per $\mathrm{g}$ of additive after 30 days), a capacity of $48.6 \mathrm{mg} / \mathrm{g}$ of oxygen absorbed was reached (Lehner, Schlemmer, \& Sängerlaub, 2015).

The use of zero valent iron nanopowders seems an interesting alternative to common iron micropowders, since their scavenging activity is much bigger due to their high surface area, and their activation is already noticed at dry conditions (Foltynowicz, Bardenshtein, Sängerlaub, Antvorskov, \& Kozak, 2017; Mu et al., 2013). According to Foltynowicz et al. (Foltynowicz et al., 2017), the oxygen scavenge rate of nanoscale iron $(10 \mathrm{~nm})$ was $2-3$ times higher at $100 \%$ relative humidity (RH) than non-nanoscale iron $(212 \mu \mathrm{m})$. The same authors also mechanically mixed the nanoscale iron in a silicon matrix, observing that the uptake of oxygen was more than 10 times faster than certain commercial films consisted of PE and PP filled with micron-sized iron powders.

Besides iron-based oxygen scavengers, palladium nanoparticles (PdNPs) are noticed as another alternative to scavenge oxygen. PdNPs in the presence of hydrogen can remove residual oxygen by catalysing the oxidation of hydrogen into water (Hutter, Rüegg, \& Yildirim, 2016). Cherpinski et al. (Cherpinski, Gozutok, Sasmazel, Torres-Giner, \& Lagaron, 2018) prepared an oxygen scavenging film of poly (3-hydroxybutyrate) (PHB) containing PdNPs (Table 1). The films presented an oxygen scavenging capability of $\sim 30 \%$ for a final time of 16.5 $\mathrm{h}$ at $100 \% \mathrm{RH}$, accompanied with improved thermal stability and mechanical properties.

The same authors developed biodegradable coatings consisted of PHB and polycaprolactone (PCL) filled with PdNPs for oxygen scavenging purposes (Table 1), using a cellulose-based packaging (e.g., paper) as support substrate for the coatings (Cherpinski, Szewczyk, Gruszczyński, Stachewicz, \& Lagaron, 2019). All the prepared multilayer systems exhibited oxygen scavenging at 50\% RH with the best 
systems being the paper/PHB-fibers/PdNPs-PCL-film and paper/PdNPs-PHB-fiber/PdNPs-PCL-film with $\sim 81 \%$ reduction at 3000 min for both systems. The oxygen scavenging capability of the PdNPs was enhanced by the incorporation of the PCL matrix, which is a more oxygen permeable material than PHB. This was supported by the excellent oxygen scavenging ability of the PdNPs-PCL film with a $\sim 100 \%$ oxygen depletion at $1250 \mathrm{~min}$ at $50 \% \mathrm{RH}$.

PdNPs coated on a PET film by magnetron sputtering technology was tested to preserve the colour of cooked cured ham (Table 1) (Hutter et al., 2016). This film allowed the scavenging of the all the oxygen within $35 \mathrm{~min}$, leading to a prolonged shelf life of 21 days by preventing the decolorization of the ham. Control samples (without PdNPs) showed increased decolorization within $2 \mathrm{~h}$ of storage. However, the oxygen scavenging capability of PdNPs is highly dependent on the hydrogen concentration in the package to promote the catalysis reaction. Recently, a review article pointed out the use of multiple metallic inorganic fillers, including iron powder, activated iron, ferrous oxide, iron salt, Co(II), zinc, and others, to be applied as oxygen scavengers in polymer films (Gaikwad et al., 2018).

Bimetallic particles are also efficient $\mathrm{M}_{0} \mathrm{~F}$ with excellent antimicrobial and UV-vis protection properties, and thus, their application to produce $\mathrm{PM}_{0} \mathrm{C}$ for food packaging applications has been performed and is represented in Table 1. For example, a PLA film filled with bimetallic silver-copper nanoparticles (Ag-CuNPs) in addition with cinnamon essential oil (CEO), was tested to serve as food package for chicken meat samples contaminated with $S$. typhimurium, L. monocytogenes, and C. jejuni bacteria (Table 1) (Ahmed, Arfat, et al., 2018). The developed films presented reduced the WVB and oxygen barrier (OB), enhanced UV-vis protection, and antibacterial activity by observing a decrease in the counts of $C$. jejuni and $S$. typhimurium in the contaminated chicken meat samples, which reached below the detection level on the 21st day, and with less activity against $L$. monocytogenes.

Additional $\mathrm{M}_{0} \mathrm{~F}$ with potential to be included in polymer matrices for food packaging applications are the selenium nanoparticles (SeNPs). These are known as synthetic antioxidants due to their free radical scavenging capability, that can serve to produce SeNPs-polymer composite films with antioxidant activity to reduce the oxidation and early maturation of the packaged food (Table 1) (Vera et al., 2016). Furthermore, the use of gold as metallic filler has showed promissing food packaging related properties, such as antimicrobial activity, reduced WVB and OB, and enhanced UV-Vis protection (Table 1) (Chowdhury, Teoh, Ong, Zaidi, \& Mah, 2020; Pagno et al., 2015). In a real food application, a AuNPs-PVA binary film enhanced the shelf life (up to 5 days) of packed bananas in comparison to the control film (Table 1) (Chowdhury et al., 2020).

\subsection{Ternary and quaternary polymer-metallic composites}

Ternary composites $\left(\mathrm{M}_{0} \mathrm{~F} 1 / \mathrm{F} 2\right)$. This type of $\mathrm{PM}_{0} \mathrm{C}$ involves adding dual-side fillers into a polymer matrix, leading to ternary $\mathrm{M}_{0} \mathrm{~F} 1 / \mathrm{F} 2$ polymer composites. Some examples of dual-side fillers $\left(\mathrm{M}_{0} \mathrm{~F} 1 / \mathrm{F} 2\right)$ used to form ternary composites with potential as food packaging are summarised in Table 2.

As representative example of a ternary $\mathrm{M}_{0} \mathrm{~F} 1 / \mathrm{F} 2$-polymer composite applied as food packaging, an AgNPs/BNC dual-side filler was produced by incorporating AgNPs into bacterial nanocellulose (BNC) by chemical and $\mathrm{UV}$-assisted reduction of the $\mathrm{Ag}^{+} / \mathrm{BNV}$ slurry. This was later used to produce a AgNPs/BNC-PVA composite by solution casting (Wang et al., 2020). This ternary film allowed enhanced WVB and OB properties, and inhibition in the growth of bacteria in packed raw beef (Table 2).

In another example, an AgNPs/Laponite dual-side filler synthesized by the reduction of an $\mathrm{Ag}^{+}$/Laponite mixture with the use of quaternized chitosan as green reductant, was used to produce an AgNPs/LaponiteChitosan ternary composite by solution casting (Wu, Huang, Li, Xiao, \& Wang, 2018). Improved mechanical, WVB, OB and water solubility properties were detected, and mainly related to the addition of the laponite. On the other hand, the observed antimicrobial activity was related to the presence of the AgNPs. This synergistic effect between laponite and the AgNPs in the AgNPs/Laponite-Chitosan composite, allowed an extension in the shelf life of litchi fruits by 7 days in comparison to the control PE and chitosan (5 days) (Table 2).

Ternary composites $\left(\mathrm{M}_{0} \mathrm{~F} 1+\mathrm{F} 2\right)$. The manufacture of ternary $\mathrm{PM}_{0} \mathrm{C}$ can also be made by the addition of the second filler separately from the $\mathrm{M}_{0} \mathrm{~F}$ (i.e., there is no pre-synthesized chemical and/or physical attachment between the fillers), and some examples are presented in Table 2. Taking a FeNPs+OMMT-PP ternary composite film as representative example, the synthesis of this ternary film involved the separate mixing of the clay powder and the iron nanoparticles with the polymer granules (polypropylene), later processed in a twin extruder to give the FeNPs+OMMT-PP film (Khalaj, Ahmadi, Lesankhosh, \& Khalaj, 2016). This composite provided enhanced barrier properties, achieving reduced values in WVB (max. of $\sim 77 \%$ ) and OB (max. of $\sim 55 \%$ ) $v$ s. neat PP control film (Table 2).

Several studies were grouped in Table 2 in which ternary $\mathrm{M}_{0} \mathrm{~F} 1+\mathrm{F} 2$ composites are applied to real food packaging. For instance, a PLA ternary composite film filled with $\mathrm{TiO}_{2}, \mathrm{AgNPs}$, and bergamot essential oil (BEO) was used to fabricate AgNPs+TiO ${ }_{2}+$ BEO-PLA films (Table 2) that allowed to maintain the quality of fresh mango for 15 days, by obtaining superior results in terms of colour, total acidity, vitamin C, weight loss, and microbial content when compared to neat PLA and BEO-PLA films (Chi et al., 2019). Other studies evidenced food preservation using AgNPs+MMT-PVA films in the package of chicken sausage (Mathew, S, Mathew, \& Radhakrishnan, 2018), AgNPs+GST-Chitosan film in the storage of wheat bread slices (Nair, Alummoottil, \& Moothandasserry, 2017), and $\mathrm{AgNPs}+\mathrm{TiO}_{2}$-PLA film in the package of cottage cheese (Li, Zhang, et al., 2017), leading to prolonged shelf life in comparison to control films, as given in Table 2.

Quaternary composites $\left(\mathrm{M}_{0} \mathrm{~F} 1 / \mathrm{F} 2 / \mathrm{F} 3\right)$. The development of new and alternative fillers, such as triple-side fillers $\left(\mathrm{M}_{0} \mathrm{~F} 1 / \mathrm{F} 2 / \mathrm{F} 3\right.$, where $\mathrm{M}_{0} \mathrm{~F}$ is the metallic filler 1, F2 is filler 2, and F3 is filler 3) has led to the manufacture of quaternary composite films as represented in Table 2, applied for food packaging (Biswas, Tiimob, Abdela, Jeelani, \& Rangari, 2019; Naskar et al., 2018; Vasile et al., 2017). As a representative example, a silver-carbon-silica (AgNPs/Carbon/ $/ \mathrm{SiO}_{2}$ ) triple-side filler was synthesized by doping a carbon-silica hybrid obtained from rice husk pyrolysis with AgNPs produced through a ball-milling process (Biswas et al., 2019). This filler was used to produce an AgNPs/Carbon/ $/ \mathrm{SiO}_{2}$-PBAT quaternary film that displayed antimicrobial action, for which the authors suggested its potential use in food packaging applications (Table 2). However, poor interaction between the polymer and the triple-side filler was evidenced, causing a decrease in the mechanical proprieties in comparison to the neat control film.

Quaternary composites $\left(\mathrm{M}_{0} \mathrm{~F} 1+\mathrm{F} 2+\mathrm{F} 3\right)$. Quaternary composite films by the separate addition of multiple fillers $\left(\mathrm{M}_{0} \mathrm{~F} 1+\mathrm{F} 2+\mathrm{F} 3\right)$ has also led to the formation of $\mathrm{PM}_{0} \mathrm{C}$ with potential use in food packaging, and some examples are displayed in Table 2. In the study from Li et al. (Table 2) (Li, Zhang, et al., 2017), the separate mixing of a AgNPs $/ \mathrm{TiO}_{2}$ nanopowder, silica, and attapulgite (clay) with a LDPE/LLDPE melt blend was performed to prepare a masterbatch. The masterbatch pellets were latter used in combination with LDPE to prepare the AgNP$\mathrm{s} / \mathrm{TiO}_{2}+\mathrm{SiO}_{2}+$ Attapulgite-LLDPE/LDPE quaternary films by a plastic extruder; latter transformed into bags using a heat sealer. An XRD (powder X-ray) analysis of the composite film evidenced the presence of $\mathrm{TiO}_{2}$ phases with no presence of $\mathrm{Ag}$ phase, suggesting their low particle size (less than $3 \mathrm{~nm}$ ). This composite was used for the storage of rice and displayed inhibition in the microorganism growth, maintenance of the rice texture (hardness, springiness, and adhesiveness), and a slow aging of the rice, in comparison to neat PE package bags as control.

An analogous system was also applied to mushrooms preservation as presented in Table 2 (Donglu et al., 2016). Few more examples are given in Table 2. A quaternary composite film composed of $\mathrm{Ag}, \mathrm{ZnO}$ and $\mathrm{CuO}$ nanoparticles melt blended with LDPE was used for the storage of 
Table 2

Ternary/quaternary polymer-metallic composites with promising potential and already applied in food packaging.

\begin{tabular}{|c|c|c|c|c|}
\hline Filler (added form; size; loading) ${ }^{1}$ & $\begin{array}{l}\text { Polymer } \\
\text { matrix } \\
\text { (process) }^{2}\end{array}$ & Polymer intrinsic properties & Food packaging properties ${ }^{3}$ & Ref. \\
\hline \multicolumn{5}{|l|}{ Ternary $\left(\mathrm{M}_{0} \mathrm{~F} 1 / \mathrm{F} 2\right)$ composite films } \\
\hline $\begin{array}{l}\mathrm{AgNPs} / \mathrm{TiO}_{2} \text { (powder; }<70 \mathrm{~nm} \text {; } \\
\quad 1.0-5.0 \mathrm{wt} \% \text { ) }\end{array}$ & $\begin{array}{l}\text { LDPE (MB } \\
\text { film) }\end{array}$ & Enhanced TES; decreased EB & $\begin{array}{l}\text { Antimicrobial: E. coli (70-95\%), S. albidoflavus } \\
(70-85 \%)\end{array}$ & $\begin{array}{l}\text { Nasab, Jalili, and Farrokhpay } \\
\text { (2018) }\end{array}$ \\
\hline $\begin{array}{l}\text { AgNPs/TiO } \\
\text { AgNPs; } 3.0,5.0 \mathrm{wt} \% \text { ) }\end{array}$ & $\begin{array}{l}\text { LDPE (MB } \\
\text { film) }\end{array}$ & - & $\begin{array}{l}\text { Food Application (mazafati dates: } 50,20,8,4{ }^{\circ} \mathrm{C} \text { / } \\
53 \mathrm{~d} \text {; pistachio: } 50,25,0,-18{ }^{\circ} \mathrm{C} / 8 \mathrm{~d} \text { ): enhanced } \\
\text { acidity, } \mathrm{pH} \text {, TSS, reducing sugars (in dates), and } \\
\text { texture (in pistachios); prolonged shelf life of dates } \\
\text { (by 53d) and pistachio (by } 8 \mathrm{~d} \text { ) vs. control (LDPE) }\end{array}$ & $\begin{array}{l}\text { Mousavi, Pour, Nasab, } \\
\text { Rajabalipour, and Barouni } \\
\text { (2015) }\end{array}$ \\
\hline $\begin{array}{l}\text { AuNPs/ } \mathrm{TiO}_{2} \text { (powder; } 45 \mathrm{~nm} \\
\text { AuNPs; } 2.5 \text { wt } \% \text { ) }\end{array}$ & SA (SC film) & $\begin{array}{l}\text { Enhanced WCA, polymer } \\
\text { degradation }\end{array}$ & $\begin{array}{l}\text { Antimicrobial: } \text { E. coli }(\sim 87-100 \% *), \text { S. aureus } \\
(\sim 90-100 \% *)\end{array}$ & Tang et al. (2018) \\
\hline $\begin{array}{l}\text { AgNPs/Kaolinite (powder; 5-60 } \\
\text { nm AgNPs; 2.0-5.0 wt\%) }\end{array}$ & PCL (SC film) & - & $\begin{array}{l}\text { Antimicrobial: } S \text {. aureus, E. coli }(100 \% *) \text {; Barrier: OB } \\
\text { (52-69\%), WVB }(52-66 \%) \text {; Migration }\left(\mathrm{HNO}_{3} \text {; RT/ }\right. \\
\left.40 \mathrm{~d} ; \mathrm{mg} / \mathrm{kg}^{*} \mathrm{~cm}^{2}\right):<0.018\end{array}$ & $\begin{array}{l}\text { Benhacine, Ouargli, and } \\
\text { Hadj-Hamou (2019) }\end{array}$ \\
\hline $\begin{array}{l}\text { AgNPs/OMMT (powder; } 2-35 \mathrm{~nm} \\
\text { AgNPs; 3.0, 5.0 wt } \% \text { ) }\end{array}$ & $\begin{array}{l}\text { CA/TEC (SC } \\
\text { film) }\end{array}$ & $\begin{array}{l}\text { Enhanced THS, TES, EM; } \\
\text { decreased \%T, EB }\end{array}$ & $\begin{array}{l}\text { Antimicrobial: E. coli, P. aeruginosa, S. enterica, } S \text {. } \\
\text { aureus; Barrier: OB }\left(\sim 8-14 \%^{*}\right) \text {; Antioxidant } \\
\text { properties (by added thymol at } 4.0,8.0 \mathrm{wt} \%) \text {; } \\
\text { UV-vis barrier }\end{array}$ & $\begin{array}{l}\text { Dairi, Ferfera-Harrar, Ramos, } \\
\text { and Garrigós (2019) }\end{array}$ \\
\hline $\begin{array}{l}\text { AgNPs/Laponite }(<100 \mathrm{~nm},<50 \\
\text { nm AgNPs; } 5 \text { wt } \%)\end{array}$ & $\begin{array}{l}\text { Chitosan (SC } \\
\text { film) }\end{array}$ & $\begin{array}{l}\text { Enhanced TES, tensile strain; } \\
\text { decreased swelling, WS }\end{array}$ & $\begin{array}{l}\text { Antimicrobial: } S \text {. aureus, E. coli, A. niger, P. citrinum; } \\
\text { Barrier: WVB (17-30\%*), OB }(98-100 \% *) \text {; Food } \\
\left.\text { application (fresh litchi fruits; } 25^{\circ} \mathrm{C} / 7 \mathrm{~d} \text { at } 75 \% \mathrm{RH}\right) \text { : } \\
\text { prolonged shelf life by } 7 \mathrm{~d} \text { vs } 5 \mathrm{~d} \text { neat } \mathrm{PE} \text { and chitosan } \\
\text { films; Migration (TRIS-HCl buffer pH } 7.4 ; 25^{\circ} \mathrm{C} \text { / } \\
74 \mathrm{~h} \text { ): } 5.6 \% \text { (AgNPs/Laponite-Chitosan); } 29.1 \% \\
\text { (AgNPs-Chitosan) }\end{array}$ & Wu et al. (2018) \\
\hline $\begin{array}{l}\text { AgNPs/Eggshell (powder; } 10-15 \\
\text { nm AgNPs; 0.5-2.0 wt\% } \\
\text { [0.23-1.15 ppm Ag]) }\end{array}$ & $\begin{array}{l}\text { PBAT/PLA } \\
\text { (MB 3D } \\
\text { printed film) }\end{array}$ & $\begin{array}{l}\text { Enhanced THS, C; decreased } \\
\text { TS, toughness }\end{array}$ & $\begin{array}{l}\text { Antimicrobial: } S \text {. enteritidis, } L \text {. monocytogenes; } \\
\text { Migration (W at } 4{ }^{\circ} \mathrm{C}, 50{ }^{\circ} \mathrm{C} / 72 \mathrm{~h} \text {, chicken breast at } \\
4{ }^{\circ} \mathrm{C} / 164 \mathrm{~h} \text { ): ND }\end{array}$ & Tiimob et al. (2017) \\
\hline $\begin{array}{l}\text { AgNPs/Alginate microbeads } \\
\text { (powder; } 190 \mu \mathrm{m} ; 10-20 \mathrm{~nm} \\
\text { AgNPs; } 5 \mathrm{wt} \%[0.20 \mathrm{mg} / \mathrm{g} \mathrm{Ag}] \text { ) }\end{array}$ & PLA (SC film) & $\begin{array}{l}\text { Enhanced YM; decreased EB, } \\
\text { failure strain }\end{array}$ & $\begin{array}{l}\text { Antimicrobial: } S \text {. aureus; Migration }(\mathrm{mg} / \mathrm{kg}) \text { : W, } \\
95 \% \text { EtOH: } 0.011-0.041\left(4{ }^{\circ} \mathrm{C}, 20^{\circ} \mathrm{C}, 40^{\circ} \mathrm{C} / 10 \mathrm{~d}\right) ; 3 \% \\
\text { AA: } 0.13 \pm 0.05\left(20^{\circ} \mathrm{C} / 10 \mathrm{~d}\right)\end{array}$ & $\begin{array}{l}\text { Kostic, Vukasinovic-Sekulic, } \\
\text { Armentano, Torre, and } \\
\text { Obradovic (2019) }\end{array}$ \\
\hline $\begin{array}{l}\text { CuNPs/Cellulose (powder; } 0.2 \% \\
\text { w/v) }\end{array}$ & $\begin{array}{l}\text { SA-P/C (SC } \\
\text { film) }\end{array}$ & $\begin{array}{l}\text { Enhanced THS, TES; } \\
\text { decreased EB, WS, T }\end{array}$ & $\begin{array}{l}\text { Antimicrobial: E. coli; Barrier: WVB }(\sim 52 \% *) \text {; } \\
\text { UV-vis barrier; Food application (coconut oil; } \\
\left.35{ }^{\circ} \mathrm{C} / 90 \mathrm{~d} \text { at } 53 \% \mathrm{RH}\right) \text { : reduced oxidation rate; } \\
\text { prolonged shelf life by } 90 \mathrm{~d}\end{array}$ & Gautam and Mishra (2017) \\
\hline $\begin{array}{l}\text { AgNPs/BNC (20-30 nm AgNPs; } 5 \\
\text { wt } \%)\end{array}$ & PVA (SC film) & Enhanced EB; decreased TES & $\begin{array}{l}\text { Antimicrobial: } E \text {. coli (max. } 7.3 \log \mathrm{CFU} / \mathrm{L} \\
\text { reduction); Barrier: WVB }(\sim 28 \% *) \text {, OB }(\sim 40 \% *) \text {; } \\
\text { Food application (normal round beef; } E \text {. coli spiked } \\
\left.\text { round beef; } 4^{\circ} \mathrm{C} / 14 \mathrm{~d}\right) \text { ): reduction in bacteria in normal } \\
\left.\text { round beef (max. of } 3 \log \mathrm{CFU} / \mathrm{cm}^{3} \text { at day } 7\right) \text {; } \\
\text { reduction of } E \text {. coli in spiked beef (max. of } 3 \text { log CFU/ } \\
\mathrm{cm}^{3} \text { at day } 10 \text { ); number of } E \text {. coli } 1 \log \mathrm{CFU} \text { lower } \\
\text { during two weeks; Migration (saline solution, } 37^{\circ} \mathrm{C} \text { / } \\
168 \mathrm{~h}, \mathrm{mg} / \mathrm{m}^{2} \text { ): max. of } 5-7 \text { at } 168 \mathrm{~h}\end{array}$ & Wang et al. (2020) \\
\hline \multicolumn{5}{|c|}{ Ternary $\left(\mathrm{M}_{0} \mathrm{~F} 1+\mathrm{F} 2\right)$ composite films } \\
\hline $\begin{array}{l}\text { AgNPs }(<150 \mathrm{~nm} ; 1 \mathrm{wt} \%)+ \\
\mathrm{TiO}_{2} \mathrm{NPs}_{(<100 \mathrm{~nm} ; 2 \mathrm{wt} \%)}\end{array}$ & PLA (SC film) & - & $\begin{array}{l}\text { Food application (fresh mango; RT/15d): improved } \\
\text { values of colour, total acidity, vitamin C, weight loss, } \\
\text { and microbial content; prolonged shelf life by } 15 \mathrm{~d} \text { vs. } \\
\text { control ( }<15 \mathrm{~d} \text { for neat PLA and BEO-PLA films) }\end{array}$ & Chi et al. (2019) \\
\hline $\begin{array}{l}\text { AgNPs }(20 \pm 15 \mathrm{~nm} ; 2.5-7.5 \mathrm{wt} \%) \\
\quad+\text { SeNPs }(50 \pm 15 \mathrm{~nm} ; 2.5-7.5 \mathrm{wt} \\
\quad \%)\end{array}$ & $\begin{array}{l}\text { FUR/Gelatin } \\
\text { (SC film) }\end{array}$ & $\begin{array}{l}\text { Enhanced EM, density, WC, } \\
\text { swelling, TES, EB; decreased } \\
\text { WS }\end{array}$ & $\begin{array}{l}\text { Antimicrobial: } \text { E. coli, } S \text {. aureus, MRSA; Barrier: } \\
\text { WVB }(\sim 2 \% *) \text {; Food application (kiwi fruits; RT/8d): } \\
\text { reduced weight loss; extension of shelf life by } 8 \mathrm{~d} \text { vs. } \\
\text { control (6d) }\end{array}$ & Jamróz et al. (2019) \\
\hline $\begin{array}{l}\text { FeNPs (colloid; } 50-70 \mathrm{~nm} \text {; } \\
0.05-0.2 \mathrm{wt} \% \text { ) }+ \text { OMMT } \\
\text { (powder; } 1.0-4.0 \mathrm{wt} \% \text { ) }\end{array}$ & PP (MB film) & $\begin{array}{l}\text { Enhanced EM, TES; decrease } \\
\text { EB }\end{array}$ & $\begin{array}{l}\text { Barrier: WVB }(\sim 0-77 \% *) \text { and OB }\left(\sim 24-55 \% \%^{*}\right) \text {; } \\
\text { Migration (cheese water; 10d): } 0.3-1.04 \mathrm{mg} / \mathrm{kg}(\mathrm{Fe}) \text {; } \\
0.053-0.06 \% \text { (OMMT) }\end{array}$ & Khalaj et al. (2016) \\
\hline $\begin{array}{l}\text { AgNPs (powder; } 10 \mathrm{~nm} ; 1 \mathrm{wt} \%)+ \\
\left.\mathrm{TiO}_{2} \text { (powder; }<100 \mathrm{~nm} ; 2 \mathrm{wt} \%\right)\end{array}$ & PLA (SC film) & - & $\begin{array}{l}\text { Food Application (Yunnan cottage cheese; } 5{ }^{\circ} \mathrm{C} \text { / } \\
25 \mathrm{~d}) \text { : inhibited growth of total bacterial count, yeasts } \\
\text { and moulds; enhanced pH, LAB (lactic acid bacteria } \\
\text { count), sensory quality, antimicrobial activity vs. PLA } \\
\text { and LDPE control films; prolonged shelf life to } 25 \mathrm{~d} \text { vs. } \\
\text { control (15d for LDPE and } 20 \mathrm{~d} \text { for PLA); Migration } \\
(\mu \mathrm{g} / \mathrm{kg}) \text { : hexane: } 127.38(\mathrm{Ti}) ; 135.58(\mathrm{Ag})\left(40^{\circ} \mathrm{C} /\right. \\
25 \mathrm{~d}) ; \text { cottage cheese: } 12.27 \pm 2.30 \text { (Ti); } 20.04 \pm 1.38 \\
(\mathrm{Ag})\left(5^{\circ} \mathrm{C} / 25 \mathrm{~d}\right)\end{array}$ & Li, Li, et al. (2018) \\
\hline $\begin{array}{l}\text { AgNPs (powder; } 10 \mathrm{~nm} ; 0.5 \mathrm{wt} \% \text { ) } \\
\quad+\mathrm{TiO}_{2} \text { (powder; }<100 \mathrm{~nm} ; 1.0 \\
5.0 \mathrm{wt} \% \text { ) }\end{array}$ & PLA (SC film) & $\begin{array}{l}\text { Enhanced EM, EB, C, THS, } \\
\text { opacity; decreased TES. }\end{array}$ & $\begin{array}{l}\text { Antimicrobial: E. coli }(51-66 \% *), L . \text { monocytogenes } \\
(55-63 \% *) ; \text { Barrier: WVB }\left(\sim 13-29 \%^{*}\right) \text {; Migration } \\
\left(25^{\circ} \mathrm{C} / 40 \mathrm{~d} ; \mu \mathrm{g} / \mathrm{kg}\right) \text { : } 50 \% \text { EtOH: 0.72-0.99 (Ti); } \\
0.8-0.9(\mathrm{Ag}) ; 3 \% \text { AA: } 2.36-3.5(\mathrm{Ti}) ; 2.8-3.3(\mathrm{Ag})\end{array}$ & Li, Zhao, et al. (2017) \\
\hline $\begin{array}{l}\text { AgNPs (in situ w/ginger extract) + } \\
\text { MMT (powder; } 25 \text { wt } \% \text { ) }\end{array}$ & PVA (SC film) & $\begin{array}{l}\text { Enhanced TES, YM; } \\
\text { decreased EB, water } \\
\text { absorption, MC, WS, water } \\
\text { holding capacity, T }\end{array}$ & $\begin{array}{l}\text { Antimicrobial: } S \text {. typhimurium }(\sim 100 \% *) \text {, S. aureus } \\
(\sim 60 \% *) \text {; UV-vis barrier; Food Application } \\
\left.\text { (chicken sausage, } 4^{\circ} \mathrm{C} / 4 \mathrm{~d}\right) \text { : inhibition of bacterial } \\
\text { growth vs. LDPE control }\end{array}$ & $\begin{array}{l}\text { Mathew, S, Mathew, and } \\
\text { Radhakrishnan (2019) }\end{array}$ \\
\hline
\end{tabular}


Table 2 (continued)

\begin{tabular}{|c|c|c|c|c|}
\hline Filler (added form; size; loading) ${ }^{1}$ & $\begin{array}{l}\text { Polymer } \\
\text { matrix } \\
\text { (process) }^{2}\end{array}$ & Polymer intrinsic properties & Food packaging properties ${ }^{3}$ & Ref. \\
\hline $\begin{array}{l}\text { AgNPs (in situ w/starch) + MMT } \\
\quad \text { (powder; } 25 \mathrm{wt} \% \text { ) }\end{array}$ & $\begin{array}{l}\text { PVA/Starch } \\
\text { (SC film) }\end{array}$ & $\begin{array}{l}\text { Enhanced TES, YM; } \\
\text { decreased EB, water } \\
\text { absorption, MC, WS, water } \\
\text { holding capacity }\end{array}$ & $\begin{array}{l}\text { Antimicrobial: } S \text {. typhimurium, S. aureus (both } \\
\sim 100 \% *) \text {; UV-vis barrier }\end{array}$ & Mathew et al. (2018) \\
\hline $\begin{array}{l}\text { AgNPs (colloid w/starch; } 5 \mathrm{~nm} ; 3 \\
\text { mL) + GST (0.5-1.5 g) }\end{array}$ & $\begin{array}{l}\text { Chitosan (SC } \\
\text { film) }\end{array}$ & $\begin{array}{l}\text { Enhanced TES, WCA; } \\
\text { decreased EB, swelling, WS, } \\
\text { MC }\end{array}$ & $\begin{array}{l}\text { Antimicrobial: } S \text {. aureus, E. coli. C. albicans; Barrier: } \\
\text { OB }\left(\sim 57 \%^{*}\right) \text {, WVB }(\sim 54 \% *) \text {; Food Application } \\
\left.\text { (wheat bread slices, } 35^{\circ} \mathrm{C} / 14 \mathrm{~d}\right) \text { : inhibited growth of } \\
\text { bacteria count }(7.13-3.84 \mathrm{log} \text { CFU/g reduction) vs. } \\
\text { control film (19.17 log CFU/g); prolonged shelf life to } \\
8-10 \mathrm{~d} \text { vs. control (4d); Migration (wheat bread slices; } \\
\left.40^{\circ} \mathrm{C} / 14 \mathrm{~d} ; \mu \mathrm{g} / \mathrm{L}\right): 2.8-3.2(7 \mathrm{~d}), 3.7-3.9 \text { (10d), } \\
4.4-4.5(14 \mathrm{~d})\end{array}$ & Nair et al. (2017) \\
\hline $\begin{array}{l}\text { AgNPs (powder; } 35-50 \mathrm{~nm} ; 1.0 \mathrm{wt} \\
\% \text { ) + BCNC (powder; } 20-30 \mathrm{~nm} \text {; } \\
2.0-6.0 \mathrm{wt} \% \text { ) }\end{array}$ & $\begin{array}{l}\text { Chitosan (SC } \\
\text { film) }\end{array}$ & $\begin{array}{l}\text { Enhanced TES, EM, C, THS, } \\
\text { WCA; decreased EB, MC, WS }\end{array}$ & $\begin{array}{l}\text { Antimicrobial: } S \text {. aureus, B. cereus, E. coli, } P . \\
\text { aeruginosa, C. albicans; Barrier: WVB }(\sim 9-26 \% *) \text {; } \\
\text { UV-vis barrier }\end{array}$ & $\begin{array}{l}\text { Salari, Khiabani, Mokarram, } \\
\text { Ghanbarzadeh, and Kafil (2018) }\end{array}$ \\
\hline $\begin{array}{l}\text { AgNPs (colloid w/starch; } 16-20 \\
\text { nm; } 1.0-7.0 \mathrm{wt} \%)+\mathrm{NC} \\
(240-280 \mathrm{~nm} ; 4.0-16.0 \mathrm{wt} \%)\end{array}$ & PVA (SC film) & $\begin{array}{l}\text { Enhanced breaking stress, } \\
\text { EB, TES, THS }\end{array}$ & $\begin{array}{l}\text { Antimicrobial: } S . \text { aureus, E. coli; Barrier: WVB } \\
(\sim 17-62 \% *)\end{array}$ & Sarwar et al. (2018) \\
\hline $\begin{array}{l}\text { AgNPs (colloid w/plant extract; } 20 \\
\mu \mathrm{g})+ \text { Laponite (powder; } 1.0-7.0 \\
\mathrm{wt} \% \text { ) }\end{array}$ & $\begin{array}{l}\text { PP (Coating } \\
\text { film) }\end{array}$ & - & $\begin{array}{l}\text { Antimicrobial: } E \text {. coli, } S \text {. aureus; Barrier: OB }(\sim 52 \% \\
\left.{ }^{*}\right) \text {, WVB }(\sim 50 \% *) \text {; Migration }(\mu / \mathrm{L}): 7.4\left(-2^{\circ} \mathrm{C}\right) ; 7.7 \\
\left(0{ }^{\circ} \mathrm{C}\right)\end{array}$ & $\begin{array}{l}\text { Vishnuvarthanan and Rajeswari } \\
\text { (2019) }\end{array}$ \\
\hline $\begin{array}{l}\text { AgNPs (UV-radiation; } 25.7-56.6 \\
\left.\text { nm; } 2-8 \mathrm{~mL} \mathrm{Ag}\left(\mathrm{NH}_{3}\right)_{2}(\mathrm{OH}) 1 \mathrm{M}\right) \\
+ \text { CNFs }(15 \pm 5 \mathrm{~nm} ; 10 \mathrm{wt} \%)\end{array}$ & $\begin{array}{l}\text { PLA (Coating } \\
\text { film) }\end{array}$ & $\begin{array}{l}\text { Enhanced C, THS, TES, YM; } \\
\text { decreased EB, water uptake }\end{array}$ & $\begin{array}{l}\text { Antimicrobial: } S \text {. aureus, E. coli; Barrier: WVB (max. } \\
\text { 60.1\%); } \\
\text { UV-vis barrier; Migration (overall migration; mg/ } \\
\mathrm{kg} \text { ): } 10 \% \text { EtOH: }<10\left(40^{\circ} \mathrm{C} / 10 \mathrm{~d}\right), 3.4-46\left(40{ }^{\circ} \mathrm{C} /\right. \\
72 \mathrm{~h}) \text {; isooctane: }<12\left(20^{\circ} \mathrm{C} / 2 \mathrm{~d}\right) ; \text { specific migration: } \\
3.4-46 \mu \mathrm{g} / \mathrm{kg} \mathrm{Ag}(10 \% \mathrm{EtOH})\end{array}$ & $\begin{array}{l}\text { Yu, Yang, Lu, Chen, and Yao } \\
\text { (2016) }\end{array}$ \\
\hline \multicolumn{5}{|c|}{ Quaternary $\left(\mathrm{M}_{0} \mathrm{~F} 1+\mathrm{F} 2+\mathrm{F} 3\right.$ or $\left.\mathrm{M} 1 / \mathrm{F} 2 / \mathrm{F} 3\right)$ composite films } \\
\hline $\begin{array}{l}\mathrm{SiO}_{2} / \text { Carbon/AgNPs }(15-100 \mathrm{~nm} \\
\mathrm{SiO}_{2} ;<100 \mathrm{~nm} \text { AgNPs; } 0.5-1.5 \\
\mathrm{wt} \%)\end{array}$ & $\begin{array}{l}\text { PBAT (SC 3D } \\
\text { printed film) }\end{array}$ & $\begin{array}{l}\text { Enhanced THS; decreased } \\
\text { mechanical properties. }\end{array}$ & $\begin{array}{l}\text { Antimicrobial: } S \text {. enteritidis; Migration (W, chicken } \\
\text { breast; } 4{ }^{\circ} \mathrm{C} / 4 \mathrm{w} \text { ): ND }\end{array}$ & Biswas et al. (2019) \\
\hline $\begin{array}{l}\text { AgNPs/ZnO/rGO (14-19 nm ZnO; } \\
28-35 \mathrm{~nm} \text { AgNPs; } 1.0,3.0 \mathrm{wt} \%)\end{array}$ & Agar (SC film) & Enhanced TES; decreased EB & $\begin{array}{l}\text { Antimicrobial: no microbial growth in the agar } \\
\text { composite film for } 90 \mathrm{~d}\end{array}$ & Naskar et al. (2018) \\
\hline $\begin{array}{l}\mathrm{Ag} / \mathrm{Cu} / \mathrm{ZnO} \text { (powder; } 15-24 \mathrm{~nm} ; \\
0.5-1.5 \mathrm{wt} \% \text { ) }\end{array}$ & PLA (MB film) & $\begin{array}{l}\text { Enhanced C, EB; decreased } \\
\text { TES, YM }\end{array}$ & 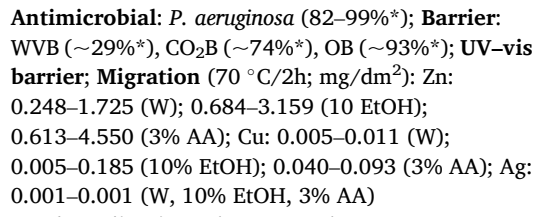 & Vasile et al. (2017) \\
\hline $\begin{array}{l}\text { AgNPs + CuONPs + ZnONPs (35; } \\
\text { 50; 20-30 nm; 0.167-1 wt.\%) }\end{array}$ & $\begin{array}{l}\text { LDPE (MB } \\
\text { film) }\end{array}$ & - & $\begin{array}{l}\text { Food Application (cheese samples, } 4{ }^{\circ} \mathrm{C} / 4 \mathrm{w} \text { ): } \\
\text { reduced coliform bacteria (max. } 4.21 \log \mathrm{CFU} / \mathrm{g} \\
\text { reduction) vs. control LDPE ( } 1.04 \mathrm{CFU} / \mathrm{g} \text { reduction) }\end{array}$ & Beigmohammadi et al. (2016) \\
\hline $\begin{array}{l}\mathrm{AgNPs}+\mathrm{TiO}_{2} \mathrm{NPs}+\text { Attapulgite }+ \\
\mathrm{SiO}_{2} \mathrm{NPs} \text { (combined powder; } \\
40-60 \mathrm{~nm} ; 15 \mathrm{wt} \% \\
[38.12-40.21 \mathrm{mg} / \mathrm{kg} \mathrm{Ag}])\end{array}$ & $\begin{array}{l}\text { LDPE/LLDPE } \\
\text { (MB film) }\end{array}$ & $\begin{array}{l}\text { Enhanced longitudinal } \\
\text { strength }\end{array}$ & $\begin{array}{l}\text { Barrier: OB }(8.0 \%) \text {, WVB }(10.5 \%) \text {; Food Application } \\
\left.\text { (mushrooms; } 4{ }^{\circ} \mathrm{C} / 14 \mathrm{~d} \text {; } 90-95 \% \mathrm{RH}\right) \text { : enhanced } \\
\text { sensory attributes; respiration rate and weight loss } \\
\text { inhibition; retention of vitamin C, proteins, and total } \\
\text { soluble solids; prolonged shelf life vs. control (LDPE); } \\
\text { Migration (mushrooms; } 4,25^{\circ} \mathrm{C} / 14 \mathrm{~d} \text { ): not } \\
\text { statistically significant }\end{array}$ & Donglu et al. (2016) \\
\hline $\begin{array}{l}\text { AgNPs/TiO }{ }_{2} \text { (powder; }<3 \mathrm{~nm} \\
\text { AgNPs; } 9.0 \mathrm{~g}[17.59 \mathrm{mg} / \mathrm{kg} \mathrm{Ag}]) \\
+ \text { Attapulgite }(4.5 \mathrm{~g})+\mathrm{SiO}_{2}(1.5 \\
\text { g) }\end{array}$ & $\begin{array}{l}\text { LDPE/LLDPE } \\
\text { (MB film) }\end{array}$ & - & $\begin{array}{l}\text { Antimicrobial: A. flavus }(\sim 92 \%) \text {; Food application } \\
\left.\text { (rice; } 37{ }^{\circ} \mathrm{C} / 1 \mathrm{~m} ; 70 \% \mathrm{RH}\right) \text { : growth inhibition of } \\
\text { mildew ( } \sim 23 \%) \text {; enhanced quality (texture and } \\
\text { pasting properties); reduced microbial population; } \\
\text { slow aging vs. control (neat PE); Migration }(\mathrm{mg} / \mathrm{kg}) \text { : } \\
3 \% \text { AA: } 0.0161-0.0255\left(37{ }^{\circ} \mathrm{C} / 6 \mathrm{~d}\right), 0.0193-0.0371 \\
\left(50{ }^{\circ} \mathrm{C} / 12 \mathrm{~h}\right) ; 10 \% \text { EtOH: ND }\left(37{ }^{\circ} \mathrm{C} / 6 \mathrm{~d} ; 50{ }^{\circ} \mathrm{C} / 12 \mathrm{~h}\right) \text {; } \\
\text { Rice: } 0.003-0.008\left(37{ }^{\circ} \mathrm{C} / 35 \mathrm{~d}\right)\end{array}$ & Li, Zhao, et al. (2017) \\
\hline
\end{tabular}

(1) $\mathrm{TiO}_{2}$ (titanium dioxide); OMMT (organically modified montmorillonite clay); BNC (bacterial nanocellulose); MTT (montmorillonite clay); GST (cassava starch granules); $\mathrm{BCNC}$ (bacterial cellulose nanocrystals); $\mathrm{NC}$ (nanocellulose); $\mathrm{SiO}_{2}$ (silicon dioxide); $\mathrm{ZnO}$ (zinc oxide); rGO (reduced graphene oxide); CuONPs (copper oxide nanoparticles); $\left({ }^{2}\right.$ ) SA (sodium alginate); CA/TEC (cellulose acetate/triethyl citrate); SA-P/C (sodium alginate-pectin/casein); FUR (furcellaran); $\left({ }^{3}\right)$ Streptomyces albidoflavus (S. albidoflavus); Salmonella enterica (S. enterica); Penicillium citrinum (P. citrinum); Salmonella enteritidis (S. enteritidis); MRSA (multi resistant Staphylococcus aureus); Candida albicans (C. albicans); Aspergillus flavus (A. flavus); ND (not detected) TSS (total soluble solids).

cheese, leading to a reduction in coliform bacteria in comparison to a LDPE control (Beigmohammadi et al., 2016). The improvement of the food packaging-related properties and the polymer intrinsic properties is clearly observed when a $\mathrm{M}_{0} \mathrm{~F}$ is added in complementation to other fillers due to the synergistic effect. This effect is exactly the purpose behind the addition of the fillers separately $\left(\mathrm{M}_{0} \mathrm{~F} 1+\mathrm{F} 2\right.$ and $\left.\mathrm{M}_{0} \mathrm{~F} 1+\mathrm{F} 2+\mathrm{F} 3\right)$ or as dual- or triple-side fillers $\left(\mathrm{M}_{0} \mathrm{~F} 1 / \mathrm{F} 2\right.$ and $\mathrm{M}_{0} \mathrm{~F} 1 / \mathrm{F} 2 / \mathrm{F} 3$ ). As will be explained in the following section of migration
(Section 4), the use of dual- or triple-side fillers are associated to the advantage of limiting the migration of the $\mathrm{M}_{0} \mathrm{~F}$, which will be connected to the toxicity of the $\mathrm{PM}_{0} \mathrm{C}$ (Section 5).

\section{Migration}

The migration is of great importance in the risk assessment regarding the toxicity and the environmental impact of the $\mathrm{PM}_{0} \mathrm{C}$. Thus, a 
meticulous understanding regarding the behaviour of particle migration is essential. The evaluation of the migration usually involves the immersion of the composite film in a food simulant (i.e., a liquid media that mimics the behaviour of actual food) under defined conditions of temperature and time, according to the guidelines of each regulatory agency (EC, 2011).

Most literature on $\mathrm{PM}_{0} \mathrm{C}$ used in food packaging perform these migration tests, having generally as the reference threshold values the ones stablished by the European Union in the Commission Regulation No. 10/2011 (EC, 2011). This regulation establishes overall migration limits (of all substances inside the film) of $10 \mathrm{mg}$ of total substance released per $\mathrm{dm}^{2}$ of food contact surface (mg/dm ${ }^{2}$ ), equivalent to $60 \mathrm{mg}$ per kg of food. Moreover, specific migration limits (one substance inside the film) are also established in $\mathrm{mg}$ of substance per $\mathrm{kg}$ of food simulant, having as examples the specific limit of $5 \mathrm{mg} / \mathrm{kg}$ for copper, $48 \mathrm{mg} / \mathrm{kg}$ for iron, and many others. For substances not authorized to be used in food contact materials, according to the list presented in the regulation, the limit of $0.01 \mathrm{mg} / \mathrm{kg}$ is applied. Therefore, investigations on the development of novel polymer-metallic packaging films usually aim to fulfil these migration limits but, at the same time, to achieve the desirable active effects.

The migration behaviour, taking binary- $\mathrm{PM}_{0} \mathrm{C}$ as the model, has been thoroughly investigated by several authors. They reached a consensus that the migration in contact with a liquid environment, such as in the case of a food simulant and consequently a food sample, can be resulted from several mechanisms or combinations of these. These mechanisms include: (i) diffusion of the particulate form from the interior of the film to the foodstuff; (ii) desorption of the particulate form at the polymerfoodstuff interface (i.e., in the surface of the film); and/or (ii) dissolution, in which, surface or internally located particles dissolve into ions ( $i$. e., metallic ions) and diffuse to the foodstuff (Duncan \& Pillai, 2015). Release caused by (iv) polymer matrix degradation due to mechanical or chemical destructive effects, is also referenced as another migration mechanism, however mostly applied to prolonged used applications ( $e$. g., in construction, vehicles, etc.) (Duncan \& Pillai, 2015).

Metallic ionic form migration. Given the migration results of several studies, some deliberations can be made regarding the migration behaviour of $\mathrm{PM}_{0} \mathrm{C}$ when in contact with food simulants and real food samples. The migration in the ionic form usually follows a general trend, in which, an increase is observed with increased loading content, immersion time, temperature and $\mathrm{pH}$ acidity of the food simulant or real food sample. For instance, Liu et al. (Liu, Hu, Zhao, Shi, \& Zhong, 2016) in a CuNPs-LDPE binary film (50 $\mathrm{nm})$ observed an increased migration rate with increased temperature (max. at $70{ }^{\circ} \mathrm{C}$ ), loading content (max. at $0.25 \mathrm{wt} \%$ ), and $\mathrm{pH}$ acidity of the food simulant (max. in $3 \%$ acetic acid). Moreover, the same authors tested the food samples of rice vinegar, bottled water and Chinese liquor, reaching a maximum release of $540 \mu \mathrm{g} / \mathrm{L}$ in the rice vinegar (the most acidic food sample).

Metak et al. (Metak, Nabhani, \& Connolly, 2015) tested the migration of a AgNPs-PE binary container and surface coated film in various food samples (orange juice, apple, cheese, ground beef, butter, bread, milk powder, carrot and water), reaching a maximum of $5.66 \mu \mathrm{g} / \mathrm{L}$ for the container and $28.92 \mu \mathrm{g} / \mathrm{L}$ for the surface coated film both in the orange juice, which is the most acidic of the used food samples. Other metallic ion migration results can support these deliberations and are presented in Table 1 (Cao et al., 2018; Jiang, Yu, Li, Zhu, \& Hu, 2019; Lomate et al., 2018).

The $\mathrm{M}_{0} \mathrm{~F}$ characteristics in terms of size and composition have also influence on the ionic migration rates, in which smaller sizes have the tendency to migrate at a higher rate, as demonstrated by Weiner et al. (Weiner, Sharma, Xu, Gray, \& Duncan, 2018) in AgNPs-LDPE binary films filled with AgNPs of multiple sizes (4, 10, 17, 23, 31, and $41 \mathrm{~nm}$ ). The authors observed that in $3 \%$ acetic acid a maximum migration rate (i.e., the migration value giving the total metal in the AgNPs-LDPE film) of $52 \%$ for the $4 \mathrm{~nm}$ AgNPs was detected, in contrast with only $0.17 \%$ for $41 \mathrm{~nm}$ AgNPs.
The same authors also observed that particle composition influenced the migration rates when using $\mathrm{AgNPs}, \mathrm{Ag}_{2} \mathrm{SNPs}$ (silver sulphide) and AuNPs as fillers (Weiner et al., 2018). Small release quantities of $\mathrm{Ag}^{+}$ $\left(0.002 \%\right.$ in acetic acid) and $\mathrm{Au}^{+/ 3+}(0.12 \%$ in water) were detected for the $\mathrm{Ag}_{2} \mathrm{SNPs}(11 \mathrm{~nm}$ ) and AuNPs (3.2 nm), respectively, in comparison to the high release of $\mathrm{Ag}^{+}$for AgNPs with similar particle sizes of $10 \mathrm{~nm}$ ( $0.56 \%$ in acetic acid) and $4 \mathrm{~nm}$ (41.08\% in water). Particle stability was pointed out as the main reason for this behaviour, and related to the dissociation energies of $216.7 \mathrm{~kJ} / \mathrm{mol}$ for $\mathrm{Ag}-\mathrm{S}\left(\mathrm{Ag}_{2} \mathrm{SNPs}\right), 226 \mathrm{~kJ} / \mathrm{mol}$ for $\mathrm{Au}-\mathrm{Au}$ (AuNPs), and $162.9 \mathrm{~kJ} / \mathrm{mol}$ for $\mathrm{Ag}-\mathrm{Ag}$ (AgNPs), with the AgNPs being more easily oxidized and less stable.

The polymer properties must also be accountable, in which the crystallinity degree, water uptake or $\mathrm{O}_{2} / \mathrm{H}_{2} \mathrm{O}$ gas permeability can play a big role in the migration behaviour. For example, Palza et al. (Palza, Quijada, \& Delgado, 2015) in several CuNPs binary films (Table 1), demonstrated that the ion release occurred in the following order: PA6 $>$ PPC18 > PP > HDPE. The higher release from PA6 and PPC18 was related to their high hydrophilic nature (water diffusion) and low crystallinity (20-25\%) in comparison to the non-polar and high crystalline (43-65\%) HDPE and PP polymers. Thus, the use of hydrophilic polymers with high levels of water uptake or $\mathrm{O}_{2} / \mathrm{H}_{2} \mathrm{O}$ gas permeability are susceptible polymer matrices to high ionic migration levels.

This is often observed in biodegradable films known for their highwater uptake, increased swelling and poor $\mathrm{O}_{2} / \mathrm{H}_{2} \mathrm{O}$ gas permeability. For instance, Cano et al. (Table 1) (Cano et al., 2016) in a AgNPs-Starch/PVA binary film, revealed migration rates of $100 \%$ of the total silver incorporated in the biodegradable film within a few hours. As causes, the high hydrophilic nature and consequent high-water uptake and swelling, favoured the high migration rates observed.

In all the reported literature here presented (Tables 1 and 2) the ionic form is regarded as the migrated form of the $\mathrm{M}_{0} \mathrm{~F}$, and thus the dissolution may be suggested as the main migration mechanism in $\mathrm{PM}_{0} \mathrm{C}$ due to $\mathrm{M}_{0} \mathrm{~F}$ oxidation. The release due to oxidation was proved by Weiner et al. (Weiner et al., 2018) that checked that the $\mathrm{Ag}^{+}$migration in a AgNPs-LDPE was 5 times lower when samples were stored under anaerobic conditions, meaning that the presence of an atmospheric aerobic condition caused the oxidation of the AgNPs and hence higher migration values.

Metallic particulate form migration. As mentioned before, the determination of the form of the migrated $\mathrm{M}_{0} \mathrm{~F}$ is critical for a careful risk assessment of the $\mathrm{PM}_{0} \mathrm{C}$ to be used in food packaging applications. Although most studies show small to negligible migration values, and thus within the regulatory threshold values, they usually do not differentiate the form in which the $\mathrm{M}_{0} \mathrm{~F}$ is migrating, whether the ionic form, particulate form, or both. As previously discussed, dissolution (metallic ionic form) is not the only possible migration mechanism, and hence, diffusion and desorption, in which the particulate form of the $\mathrm{M}_{0} \mathrm{~F}$ migrates, may be present. For example, Mackevica et al. (Mackevica, Olsson, \& Hansen, 2016) in commercial packaging products containing $\mathrm{Ag}$ particles, detected both the presence of the ionic and the particulate $(10-100 \mathrm{~nm})$ form of $\mathrm{Ag}$ in all food simulants (3\% acetic acid, water and $10 \% \mathrm{EtOH}$ ) with the use of TEM (transmission electron microscopy) analysis, and concluded a general trend of the ionic Ag being higher in the $3 \%$ acetic acid, and the particulate $\mathrm{Ag}$ higher in water and $10 \%$ EtOH.

In another study, Artiaga et al. (Artiaga, Ramos, Ramos, Cámara, \& Gómez-Gómez, 2015) using a commercial food package containing AgNPs, detected particulate AgNPs (40-60 nm) in both 3\% acetic acid and water simulants by using the $\mathrm{AF}^{4}$-ICP-MS (asymmetric flow field flow fractionation coupled inductively coupled plasma-mass spectrometry) technique. Furthermore, Metak et al. (Metak et al., 2015) tested the migration of commercial PE films surface coated with AgNPs with real food samples, and detected particulate Ag with sizes between 100-300 $\mathrm{nm}$ and $5-10 \mathrm{~nm}$ in a milk powder and orange juice sample, respectively, using SEM (scanning electron microscopy) and TEM analysis.

Solutions to hinder migration. As migration is directly related to 
the safety regarding the use of $\mathrm{PM}_{0} \mathrm{C}$ as food packaging, solutions to hinder the migration (especially of the particulate form) could help achieve a control over the release, and hence assured safety. Pointing off some examples, for instance, the use of ternary or quaternary composite films, in which the $\mathrm{M}_{0} \mathrm{~F}$ is added separately or physically/chemically immobilized (i.e., dual- or triple-side fillers) with other inorganic fillers, may have potential to hamper the release of the $\mathrm{M}_{0} \mathrm{~F}$. This is mostly due to (i) a synergistic improvement of the polymer properties related to migration (e.g., water uptake, $\mathrm{O}_{2} / \mathrm{H}_{2} \mathrm{O}$ gas permeability or crystallinity), and (ii) due to the fact that the $\mathrm{M}_{0} \mathrm{~F}$, in the case of the dual- and tripleside fillers, is physically/chemically immobilized, which in turn can delay the release of the metallic ions (since the oxidation of the $\mathrm{M}_{0} \mathrm{~F}$ is obstructed) and inhibit the migration in the particulate form.

Various examples are discussed in Table 2, where we can see that the migration levels detected in ternary or quaternary composite films are usually low (Biswas et al., 2019; Tiimob et al., 2017; Vishnuvarthanan \& Rajeswari, 2019; Wang et al., 2020). A good example on how the use of a dual-side filler can hinder the migration of the $\mathrm{M}_{0} \mathrm{~F}$, is described in the study by Wu et al. (Wu et al., 2018) in which the incorporation of an AgNPs/Laponite dual-side filler into a chitosan film allowed a decrease in the migration rate (4.4-4.6\%) in comparison to the AgNPs-chitosan film (26.5-29.1\%), and this was related to the improved water uptake and $\mathrm{O}_{2}$ gas permeability in the AgNPs/Laponite-chitosan binary film.

\section{Regulation aspects and human toxicity impact}

Regulations regarding to the specific use of $\mathrm{M}_{0} \mathrm{~F}$ (i.e., zero valent metallic micro-/nanoparticles) added alone (binary) or in complementation with other fillers (ternary and quaternary) as food contact substances/materials (FCS) is relatively poor. Indeed, by performing a thorough search in both FDA (United States Food and Drug Administration) and EFSA (European Food Safety Authority) databases, a dual-side filler named silver-silica, consisting of a microscale material with the AgNPs coated within the ceramic matrix (silica), is found approved by the FDA to provide antimicrobial action (FDA, 2020). Other related materials to impart antimicrobial action as FCS can be highlighted, such as silver-containing glass, silver-sodium-hydrogen-zirconium-phosphate, silver chloride coated onto titanium dioxide, or modified zeolites with ionic silver, copper and/or zinc. However, in these substances, the metal is added in the form of a metallic ion and not as a $\mathrm{M}_{0} \mathrm{~F}$ (EC, 2020a, 2020b; FDA, 2020).

The use $\mathrm{M}_{0} \mathrm{~F}$ as FCS is clearly limited, and most of the approved inorganic substances in the nanoform fall within the category of metal oxides (such as titanium nitride, silica, iron oxide, titanium oxide surface-treated with fluoride-modified alumina, zinc oxide, etc.), carbon black and clays, subjected to certain size restrictions (Garcia et al., 2018; $\mathrm{He}$ et al., 2019). Interestingly, the EU regulation on food additives classifies silver (Ag, E174), gold (Au, E175), and aluminium (Al, E173) in their elemental form as approved food additives (EC, 2020a, 2020b). The EFSA has re-evaluated silver (E174) and gold (E175) as food additives, and concluded that the available information concerning the toxicity was insufficient to perform a risk assessment, and recommendations regarding the inclusion of the mean particle size and distribution present in the powder form, is recommended (EFSA, 2016a; 2016b).

Despite the lack of approval in the use of $\mathrm{M}_{0} \mathrm{~F}$ as FCS, the agencies are fully aware of the spread in the development of $\mathrm{PM}_{0} \mathrm{C}$ films with the intention to be applied in food packaging. To this aim, both FDA and EFSA have release several guidance's for industry to fully evaluate the use of nanomaterials in food ingredients and food contact substances (Garcia et al., 2018). The EFSA, for example, has released a document that provides guidance on risk and safety assessment on the application of nanoscience and nanotechnologies in the food and feed chain, to assist the industry in assuring the safety of their products (Hardy et al., 2018).

This document provides guidance on (i) the correct definition of a nanomaterial ( $\geq 50 \%$ of the particle size distribution must be in the size range of $1-100 \mathrm{~nm}$ ); (ii) the necessary information regarding the nanomaterial characterization to properly assess the material safety; and (iii) the steps regarding the testing of the toxicological profile of nanomaterials. A highlighted expression used in this guidance, and important to assess the safety of a nanomaterial, is the "stability parameter" that is related to the point in which the nanomaterial losses its nano specific properties (i.e., "transformed" to a non-nanosized material), happening due to high degradation rates under certain environments (e.g., dissolution in water), or the formation of larger aggregates of sizes superior than $100 \mathrm{~nm}$.

These guidance's reflect the importance of treating a nano-based product as a "case-by-case" or "product-by-product" analysis to assess the risk of the nanomaterial, since due to the enormous physicochemical differences that nanosized materials have in contrast to its corresponding elemental and bulk (not in nanoscale) form, conventional safety procedures and regulations cannot be applied to their nanosized form (Garcia et al., 2018; Hardy et al., 2018). In relation to the human health impact by the use of $\mathrm{PM}_{0} \mathrm{C}$ films as food packaging, the migration of the $\mathrm{M}_{0} \mathrm{~F}$ (especially in the particulate form; however high levels of ionic metals are also problematic) into the foodstuffs could lead to their ingestion, having as the major unsettling matter, when the particulate form migrates into the foodstuff.

As an example of a safety evaluation by the EFSA of an iron/ bentonite $(8-20 \mu \mathrm{m}$ size) dual-side filler fabricated by NanoBioMatters Industries (Spain) to be applied as food contact material, concluded that the material dues not raise a safety concern for consumers with a maximum loading of $15 \% \mathrm{w} / \mathrm{w}$, giving the migration levels of iron (4.5 $\mathrm{mg} / \mathrm{kg})$ and aluminium $(0.3 \mathrm{mg} / \mathrm{kg})$ being smaller than the regulated threshold values for iron $(48 \mathrm{mg} / \mathrm{kg}$ ) and aluminium $(0.8 \mathrm{mg} / \mathrm{kg}$ ) (EFSA, 2012). However, it is important to mention that despite the safety report did not indicate the presence of nanomaterial, in a paper of the same year of an iron/kaolinite, also manufactured by NanoBioMatters Industries (Spain), an iron average particle size of $115 \mathrm{~nm}$ with a distribution of 75-220 nm immobilized within the kaolinite was detected, thus confirming the presence of nanomaterials (Busolo \& Lagaron, 2012). This dual-side filler was melt-blended with HDPE and LLDPE for oxygen scavenging purposes, and the authors showed negligent iron and aluminium migration values in water and isooctane as compared to standard threshold values. However, the evaluation of the presence of migrated iron particles was not performed and should be an additional safety measure to be implemented. Certain authors did evaluate the toxicological impact of $\mathrm{PM}_{0} \mathrm{C}$ films as presented in Table 3 .

Based on these studies, the cytotoxicity is clearly related to the migration capability of the $\mathrm{M}_{0} \mathrm{~F}$ amount in both the ionic and the particulate form, in which thermoplastic based metallic composite films demonstrated lower cytotoxicity effects (Jiang et al., 2019; Oliani et al., 2017) in comparison to biodegradable based polymer matrices (Basak et al., 2018; Wu et al., 2018). This was related to the migration differences between both polymeric matrices (as discussed in section 4). For instance, in a study by Palza et al. (Palza, Galarce, Bejarano, Beltran, \& Caviedes, 2017), the authors stated that the highest toxicity for the CuNPs-alginate (Table 3) was due to both the migration of the ionic and particulate inorganic form, in contrast to the only ionic form migration in the PP-CuNPs film. When the $\mathrm{M}_{0} \mathrm{~F}$ is added in the form of a dual-side filler, the cytotoxicity effect decreased in comparison to the sole addition of the $\mathrm{M}_{0} \mathrm{~F}$ (as binary film). This fact was related to metallic migration constrains (Sarwar, Niazi, Jahan, Ahmad, \& Hussain, 2018; Wu et al., 2018), as discussed in Section 4. The lack of more profound investigations regarding the toxicity of $\mathrm{M}_{0} \mathrm{~F}$ inside a polymeric matrix is evident, and based on these results, a careful inspection of the migration is strictly necessary in order to fully evaluate the toxicity impact of such materials.

\section{Environmental impact}

Another aspect of great importance is the environmental impact that the implementation of polymer-metallic composite films may cause. 
Table 3

Cytotoxicity studies of polymer-metallic composite films.

\begin{tabular}{|c|c|c|c|}
\hline $\begin{array}{l}\text { Polymer-metallic } \\
\text { composite film }\end{array}$ & Procedure $^{1}$ & Cytotoxicity & Ref. \\
\hline $\begin{array}{l}\text { AgNPs-Gelatin/ } \\
\text { PVA (SC film) }\end{array}$ & $\begin{array}{l}\text { MTT assay; } \\
\text { PBMC cell line }\end{array}$ & $\begin{array}{l}\text { Cell viability of the film }(0.1 \\
\text { mM Ag) was } \sim 84.14 \% \text {; } \\
\text { Classified as light poisonous } \\
\text { ( } 75-99 \% \text { cell viability) }\end{array}$ & $\begin{array}{l}\text { Basak } \\
\text { et al. } \\
(2018)\end{array}$ \\
\hline $\begin{array}{l}\text { CuNPs-PP (MB } \\
\text { film) }\end{array}$ & $\begin{array}{l}\text { MTT assay; L02 } \\
\text { cell line }\end{array}$ & $\begin{array}{l}\text { Cells treated with } \mathrm{Cu}^{2+} \text { with } \\
\text { varied concentrations } \\
(0-80.0 \mu \mathrm{g} / \mathrm{g}) \text {; Significant } \\
\text { inhibition on cell viability } \\
\text { was observed starting from } \\
\text { the } 10.0 \text { ( } 70 \% \text { cell viability) } \\
\text { to } 80.0(20 \% \text { cell viability) } \\
\mu \mathrm{g} / \mathrm{g} \text { concentrations; Giving } \\
\text { the maximum migration of } \\
4.5 \mu \mathrm{g} / \mathrm{g} \text { from the CuNPs-PP } \\
(1.0 \mathrm{wt} \%) \text {, the film was } \\
\text { considered safe to use }\end{array}$ & $\begin{array}{l}\text { Jiang } \\
\text { et al. } \\
(2019)\end{array}$ \\
\hline $\begin{array}{l}\text { AgNPs-PP (MB } \\
\text { film) }\end{array}$ & $\begin{array}{l}\text { ISO } 10993- \\
\text { 5:2009; NCTC } \\
\text { L929 cell line }\end{array}$ & $\begin{array}{l}\text { Film samples ( } 0.1-4.0 \mathrm{wt} \% \\
\text { of AgNPs) were } \\
\text { characterized as } \\
\text { noncytotoxic (above } 50 \% \\
\text { cell viability) }\end{array}$ & $\begin{array}{l}\text { Oliani } \\
\text { et al. } \\
(2017)\end{array}$ \\
\hline $\begin{array}{l}\text { CuNPs-PP (MB } \\
\text { film); CuNPs- } \\
\text { Alginate (SC } \\
\text { film) }\end{array}$ & $\begin{array}{l}\text { MTT assay; CNh } \\
\text { and SaOS- } 2 \text { cell } \\
\text { line }\end{array}$ & $\begin{array}{l}\text { CuNPs-alginate }(0.5-5.0 \mathrm{wt} \\
\% \text { CuNPs) presented }<40 \% \\
\text { viability in both cell lines vs } \\
\text { alginate control ( } \sim 40 \% \\
\text { viability); CuNPs-PP films } \\
(10,20 \text { wt } \% \text { CuNPs) } \\
\text { presented } 60-70 \% \text { viability } \\
\text { vs control PP ( } 60-70 \%) \text { in } \\
\text { CNh cells, and } 50-60 \% \\
\text { viability vs. control PP } \\
(50-60 \%) \text { in SaOS- } 2 \text { cells }\end{array}$ & $\begin{array}{l}\text { Palza } \\
\text { et al. } \\
\text { (2017) }\end{array}$ \\
\hline $\begin{array}{l}\text { AgNPs+NC-PVA } \\
\text { (SC film) }\end{array}$ & $\begin{array}{l}\text { MTT assay; } \\
\text { HepG2 cell line }\end{array}$ & $\begin{array}{l}\text { Non-toxic effect for AgNPs } \\
(1.0,3.0 \mathrm{wt} \%)+\mathrm{NC}(12 \mathrm{wt} \\
\%)-P V A \text { films at the } \\
\text { concentrations of } 35-250 \\
\mu \mathrm{g} / \mathrm{mL} \text { by obtaining a cell } \\
\text { viability higher than } 90 \%\end{array}$ & $\begin{array}{l}\text { Sarwar } \\
\text { et al. } \\
\text { (2018) }\end{array}$ \\
\hline $\begin{array}{l}\text { AgNPs/Laponite- } \\
\text { Chitosan (SC } \\
\text { film) }\end{array}$ & $\begin{array}{l}\text { MTT assay; L02 } \\
\text { cell line }\end{array}$ & $\begin{array}{l}\text { Cell viability of AgNPs/ } \\
\text { Laponite-Chitosan, pure } \\
\text { Chitosan, and AgNPs- } \\
\text { Chitosan were } 85.81,90.37 \text {, } \\
\text { and } 41.51 \% \text {, respectively, } \\
\text { using } 10 \mathrm{mg} \text { film samples }\end{array}$ & $\begin{array}{l}\text { Wu et al. } \\
\text { (2018) }\end{array}$ \\
\hline
\end{tabular}

(1) MTT (3-[4,5-dimethylthiazol-2-yl]-2,5-diphenyltetrazolium bromide assay); PBMC (primary peripheral blood mononuclear human cells); L02 (human normal hepatocyte cell line); ISO10993-5:2009 (biological evaluation of medical devices part 5: tests for in vitro cytotoxicity); NCTC L929 (mouse fibroblast cell line); CNh (cerebral cortex of normal fetal mice cell line); SAOS-2 (human osteosarcoma cell line); HepG2 (human hepatocellular carcinoma cell line).

Even if the fabricated composites are effective as active food package and comply with the migration regulation limits, the question regarding the effects that can cause in the environment has been raising concern among the scientific community. Are the benefits of using $\mathrm{PM}_{0} \mathrm{C}$ food packaging materials outweighed by the possible environmental burden? Indeed, very few investigations study the real effect of these materials in the environment. In the last couple of years, an increase amount of studies has been focused on the use of life cycle assessment (LCA) as a systematic tool for determining the environmental impact of metalbased food packaging products by considering the different stages of the product lifetime, such as the raw materials used in the composite film manufacture, the manufacturing process, usage time, and end of life or disposal (Westerband \& Hicks, 2018a).

In an LCA study, the environmental impact of hypothetical PE containers filled with AgNPs containing a high $(766 \mu \mathrm{g})$ or low $(65 \mu \mathrm{g})$ load was evaluated (Westerband \& Hicks, 2018a). The study resulted in an insignificant increase (less than $2 \%$ ) of the overall environmental impact in the ecotoxicity, carcinogens, non-carcinogens, eutrophication and ozone depletion, compared to conventional packages. As conclusion, the impact in the addition and leaching of AgNPs is minimal $v$ s. the advantages in reducing food waste, making it a viable option to use as food packaging materials. The same authors, (Westerband \& Hicks, 2018b) used LCA to evaluate the environmental impacts of the same hypothetical AgNPs-PE containers in the storage of food samples (chicken, bread and orange juice). In the categories of global warming (0-64\% reduction) and acidification ( $\sim 12 \%$ reduction for chicken and $\sim 1200 \%$ reduction for orange juice), the use of AgNPs-PE allowed a decrease in those categories in function of the extended lifetime, suggesting the environmental benefit of using AgNPs enable food containers. However, in the category of ozone depletion, an increase in the environmental impact was observed. Thus, in conclusion, the authors stated that the potential environmental benefit is highly dependent on the environmental impact of the stored food.

Pourzahedi et al. (Pourzahedi, Vance, \& Eckelman, 2017) performed an LCA study for 15 commercially available AgNPs-filled products. The environmental impact strongly depended on the silver loading (superior than 10\%) and type of product, affecting all environmental categories (ozone depletion, global warming, photochemical smog, acidification, eutrophication, human heath: carcinogens, human health: non-carcinogens; human heath: criteria air pollutants, ecotoxicity and fossil fuel depletion) with increases between 1 and 99\%. Moreover, the metal precursors, heating requirements, and electricity consumption in the AgNPs synthesis method, strongly influenced the environmental impact with increases as high as $300 \%$ in eutrophication, carcinogenic, non-carcinogenic and ecotoxicity impact, $100 \%$ for acidification, $230 \%$ for smog, and $20 \%$ for ozone depletion, global warming and fossil fuel depletion. This was done by comparing physical (e.g., flame spray pyrolysis), chemical (with sodium borohydride or trisodium citrate) and bio-based synthesis methods, with the physical method having the greatest impact level. The authors also evaluated the ecotoxicity effect of the migrated $\mathrm{Ag}$ from the products, and by considering the product with the highest migration, the food container ( $7.95 \mathrm{mg} \mathrm{Ag}$; $2 \%$ release), the authors concluded that it has 2-12 times less ecotoxicity than the food container itself, considering all possible transformations and processes that can happen on the released Ag occurring during waste water treatment, such as sulfidation reaction, dissociation into ions, etc.

In another investigation, Bi et al. (Bi et al., 2018) evaluated by LCA the environmental impact of a commercial antimicrobial container of PP containing silver $(8.8 \pm 0.6 \mathrm{Ag} \mu \mathrm{g} / \mathrm{g}$ of polymer; $>300 \mathrm{~nm}$ particle size $)$ considering three different lifecycle phases: raw manufacture of the container, silver release during dishwashing and during landfill disposal. After the dishwashing experiment at $60{ }^{\circ} \mathrm{C}$, the total $\mathrm{Ag}$ released was of $23 \mathrm{ng} / \mathrm{g}(0.25 \%)$ with detergent and $13 \mathrm{ng} / \mathrm{g}(0.13 \%)$ with only water, suggesting the detergent role in promoting migration. Detectable Ag sizes in the dishwashing extracts by using sp-ICP-MS were of $40 \mathrm{~nm}$ to more than $100 \mathrm{~nm}$ when using detergent, and $40-90 \mathrm{~nm}$ using only water, and interestingly, the size of the detected particles decreased with increasing washing cycles (4 in total). Landfill silver release was evaluated by a toxicity characteristic leaching protocol (TCLP) to evaluate the hazardousness of a waste, where less than $1 \mu \mathrm{g} / \mathrm{L}$ during a $18 \mathrm{~h}$ test was detected, which is lower than the $5 \mathrm{mg} / \mathrm{L}$ threshold value to be considered toxic in disposal. Regarding the environmental impact, increases in all environmental impact categories are detected and vary between 0.05 and $1.4 \%$, with the highest impacts in ozone depletion $(0.81 \%)$, carcinogenic $(1.38 \%)$, noncarcinogenic $(0.80 \%)$ and ecotoxicity $(<0.2 \%)$. Moreover, the authors performed an antibacterial test against $E$. coli, and found insignificant effects in the reduction of the bacterial count. In conclusion, the additional environmental burden (although being very small) in comparison to the potential health risks associated to nanoparticle migration and the fact that no antibacterial activity was detected, the incorporation of silver was considered unnecessary.

Based on the mentioned literature, the environmental impacts of $\mathrm{PM}_{0} \mathrm{C}$ can vary in terms of the filler loading degree, type of synthesis 
methods to manufacture the $\mathrm{M}_{0} \mathrm{~F}$, and the initial environmental impact of the food to be stored. The toxicity and environmental impact are also strictly related to the migration capability of the ionic or particulate form, and hence, strict regulations must be implemented in the migration evaluation. Indeed, this is all for nothing if the addition of the $\mathrm{M}_{0} \mathrm{~F}$ does not perform its activity. It is very important to double-check if the active property is present, prior to their market entry, so that no unnecessary environmental burden and human toxicity related problems are generated (Bi et al., 2018).

\section{Conclusions}

Polymer-metallic composite films exhibit promising potential to be used in the food packaging industry. Antimicrobial activity, scavenging abilities, or antioxidant effects are some of the active properties that the metallic particles can add to a polymeric film. In consequence, their application as food packaging options (i.e., as containers, bags, etc.) have a positive effect on the extension of food shelf life, safety and quality, and hence, diminishing food waste.

Despite the advantages, special care must be taking regarding the migration behaviour of such fillers, especially in the particulate released form, since it is directly connected to an increased toxicity and environmental impact. A proper characterization with more sensitive analytical techniques of the migration extracts is a necessity, in order to effectively detect the type of migration form (particulate or ionic) of the metallic filler. This will aid in understanding the stability of the metallic fillers outside of the polymeric matrix, in terms of dissolution, aggregation, or other physicochemical changes, which is an important parameter to evaluate the risk level of the composite film.

The development of this type of composite films is advancing in an enormous rate, and the regulation regarding the use of metallic micro-/ nanoparticles in food contact materials, needs to be in the same pace. Proper risk assessments regarding human toxicity (e.g. by stablishing certain migration acceptable levels for human safety) and the effective evaluation and confirmation of the advantages on the use of metallic particles is needed, so that the regulation and legislation can advance into the approval of this type of materials for food contact packaging. Research in the development of strategies to mitigate and control the release of the metallic filler may pose as an interesting field so that the negative consequences in terms of toxicity and environmental impact can be minimal.

\section{Author contributions}

Diogo Videira-Quintela: conceptualization; investigation; methodology; roles/writing - original draft; writing - review \& editing; Olga Martin: conceptualization; methodology; visualization; writing - review \& editing; supervision; Gemma Montalvo: conceptualization; methodology; visualization; writing - review \& editing; supervision.

\section{Declaration of competing interest}

None.

\section{Acknowledgments}

Diogo Videira-Quintela thanks the University of Alcalá for his $\mathrm{PhD}$ scholarship (FPI-UAH). This work was supported by the University of Alcalá [Grant No. CCG2018/EXP-039]; and the Ministry of Science and Innovation of Spain [Grant No. MAT2014-57557-R].

\section{References}

Ahmed, J., Arfat, Y. A., Bher, A., Mulla, M., Jacob, H., \& Auras, R. (2018). Active chicken meat packaging based on polylactide films and bimetallic Ag-Cu nanoparticles and essential oil. Journal of Food Science, 83, 1299-1310. https://doi.org/10.1111/17503841.14121
Ahmed, J., Mulla, M., Arfat, Y. A., Bher, A., Jacob, H., \& Auras, R. (2018b). Compression molded LLDPE films loaded with bimetallic (Ag-Cu) nanoparticles and cinnamon essential oil for chicken meat packaging applications. Lebensmittel-Wissenschaft und -Technologie- Food Science and Technology, 93, 329-338. https://doi.org/10.1016/j. lwt.2018.03.051

AMERIPEN. (2020). Value of packaging in reducing food waste Accessed https://www. ameripen.org/page/Publications. (Accessed 27 May 2020).

Arfat, Y. A., Ahmed, J., \& Jacob, H. (2017). Preparation and characterization of agarbased nanocomposite films reinforced with bimetallic (Ag-Cu) alloy nanoparticles. Carbohydrate Polymers, 155, 382-390. https://doi.org/10.1016/j. carbpol.2016.08.097

Arfat, Y. A., Ejaz, M., Jacob, H., \& Ahmed, J. (2017). Deciphering the potential of guar gum/Ag-Cu nanocomposite films as an active food packaging material. Carbohydrate Polymers, 157, 65-71. https://doi.org/10.1016/j.carbpol.2016.09.069

Ariyarathna, I. R., Rajakaruna, R. M. P. I., \& Karunaratne, D. N. (2017). The rise of inorganic nanomaterial implementation in food applications. Food Control, 77, 251-259. https://doi.org/10.1016/j.foodcont.2017.02.016

Artiaga, G., Ramos, K., Ramos, L., Cámara, C., \& Gómez-Gómez, M. (2015). Migration and characterisation of nanosilver from food containers by AF4-ICP-MS. Food Chemistry, 166, 76-85. https://doi.org/10.1016/j.foodchem.2014.05.139

Azlin-Hasim, S., Cruz-Romero, M. C., Morris, M. A., Cummins, E., \& Kerry, J. P. (2015). Effects of a combination of antimicrobial silver low density polyethylene nanocomposite films and modified atmosphere packaging on the shelf life of chicken breast fillets. Food Packaging and Shelf Life, 4, 26-35. https://doi.org/10.1016/j. fpsl.2015.03.003

Basak, P., Das, P., Biswas, S., Biswas, N. C., \& Mahapatra, G. K. D. (2018). Green synthesis and characterization of gelatin-PVA silver nanocomposite films for improved antimicrobial activity. IOP Conference Series: Materials Science and Engineering, 410, Article 012019. https://doi.org/10.1088/1757-899x/410/1/ 012019

Beigmohammadi, F., Peighambardoust, S. H., Hesari, J., Azadmard-Damirchi, S., Peighambardoust, S. J., \& Khosrowshahi, N. K. (2016). Antibacterial properties of LDPE nanocomposite films in packaging of UF cheese. Lebensmittel-Wissenschaft und -Technologie- Food Science and Technology, 65, 106-111. https://doi.org/10.1016/j. lwt.2015.07.059

Benhacine, F., Ouargli, A., \& Hadj-Hamou, A. S. (2019). Preparation and characterization of novel food packaging materials based on biodegradable PCL/Ag-kaolinite nanocomposites with controlled release properties. Polymer-Plastics Technology and Materials, 58, 328-340. https://doi.org/10.1080/03602559.2018.1471714

Biswas, M. C., Tiimob, B. J., Abdela, W., Jeelani, S., \& Rangari, V. K. (2019). Nano silicacarbon-silver ternary hybrid induced antimicrobial composite films for food packaging application. Food Packaging and Shelf Life, 19, 104-113. https://doi.org/ 10.1016/j.fpsl.2018.12.003

Bi, Y., Westerband, E. I., Alum, A., Brown, F. C., Abbaszadegan, M., Hristovski, K. D., et al. (2018). Antimicrobial efficacy and life cycle impact of silver-containing food containers. ACS Sustainable Chemistry \& Engineering, 6, 13086-13095. https://doi. org/10.1021/acssuschemeng.8b02639

Bumbudsanpharoke, N., Lee, W., \& Ko, S. (2018). A comprehensive feasibility study on the properties of LDPE-Ag nanocomposites for food packaging applications. Polymer Composites, 39, 3178-3186. https://doi.org/10.1002/pc.24325

Busolo, M. A., \& Lagaron, J. M. (2012). Oxygen scavenging polyolefin nanocomposite films containing an iron modified kaolinite of interest in active food packaging applications. Innovative Food Science \& Emerging Technologies, 16, 211-217. https:// doi.org/10.1016/j.ifset.2012.06.008

Cano, A., Cháfer, M., Chiralt, A., \& González-Martínez, C. (2016). Development and characterization of active films based on starch-PVA, containing silver nanoparticles. Food Packaging and Shelf Life, 10, 16-24. https://doi.org/10.1016/j.fpsl.2016.07.002

Cao, G., Lin, H., Kannan, P., Wang, C., Zhong, Y., Huang, Y., et al. (2018). Enhanced antibacterial and food simulant activities of silver nanoparticles/polypropylene nanocomposite films. Langmuir, 34, 14537-14545. https://doi.org/10.1021/acs. langmuir.8b03061

Cherpinski, A., Gozutok, M., Sasmazel, H. T., Torres-Giner, S., \& Lagaron, J. M. (2018). Electrospun oxygen scavenging films of poly(3-hydroxybutyrate) containing palladium nanoparticles for active packaging applications. Nanomaterials, 8, 469. https://doi.org/10.3390/nano8070469

Cherpinski, A., Szewczyk, P. K., Gruszczyński, A., Stachewicz, U., \& Lagaron, J. M. (2019). Oxygen-scavenging multilayered biopapers containing palladium nanoparticles obtained by the electrospinning coating technique. Nanomaterials, 9, 262. https://doi.org/10.3390/nano9020262

Chi, H., Song, S., Luo, M., Zhang, C., Li, W., Li, L., et al. (2019). Effect of PLA nanocomposite films containing bergamot essential oil, TiO2 nanoparticles, and Ag nanoparticles on shelf life of mangoes. Scientia Horticulturae, 249, 192-198. https:// doi.org/10.1016/j.scienta.2019.01.059

Chowdhury, S., Teoh, Y. L., Ong, K. M., Zaidi, N. S. R., \& Mah, S.-K. (2020). Poly(vinyl) alcohol crosslinked composite packaging film containing gold nanoparticles on shelf life extension of banana. Food Packaging and Shelf Life, 24, 100463. https://doi.org/ 10.1016/j.fpsl.2020.100463

Dairi, N., Ferfera-Harrar, H., Ramos, M., \& Garrigós, M. C. (2019). Cellulose acetate/ AgNPs-organoclay and/or thymol nano-biocomposite films with combined antimicrobial/antioxidant properties for active food packaging use. International Journal of Biological Macromolecules, 121, 508-523. https://doi.org/10.1016/j. ijbiomac.2018.10.042

Devi, M. P. I., Nallamuthu, N., Rajini, N., Kumar, T. S. M., Siengchin, S., Rajulu, A. V., et al. (2019a). Antimicrobial properties of poly(propylene) carbonate/Ag nanoparticle-modified tamarind seed polysaccharide with composite films. Ionics, 25, 3461-3471. https://doi.org/10.1007/s11581-019-02895-9 
Devi, M. P. I., Nallamuthu, N., Rajini, N., Kumar, T. S. M., Siengchin, S., Rajulu, A. V., et al. (2019b). Biodegradable poly(propylene) carbonate using in-situ generated CuNPs coated Tamarindus indica filler for biomedical applications. Materials Today Communications, 19, 106-113. https://doi.org/10.1016/j.mtcomm.2019.01.007

Donglu, F., Wenjian, Y., Kimatu, B. M., Mariga, A. M., Liyan, Z., Xinxin, A., et al. (2016) Effect of nanocomposite-based packaging on storage stability of mushrooms (Flammulina velutipes). Innovative Food Science \& Emerging Technologies, 33, 489-497. https://doi.org/10.1016/j.ifset.2015.11.016

Duncan, T. V. (2011). Applications of nanotechnology in food packaging and food safety: Barrier materials, antimicrobials and sensors. Journal of Colloid and Interface Science, 363, 1-24. https://doi.org/10.1016/j.jcis.2011.07.017

Duncan, T. V., \& Pillai, K. (2015). Release of engineered nanomaterials from polymer nanocomposites: Diffusion, dissolution, and desorption. ACS Applied Materials \& Interfaces, 7, 2-19. https://doi.org/10.1021/am5062745

Ebrahimiasl, S., \& Rajabpour, A. (2015). Synthesis and characterization of novel bactericidal $\mathrm{Cu} / \mathrm{HPMC}$ BNCs using chemical reduction method for food packaging. Journal of Food Science \& Technology, 52, 5982-5988. https://doi.org/10.1007/ s13197-014-1615-0

EC. (2011). Commission regulation (EU) No 10/2011 of 14 january 2011 on plastic materials and articles intended to come into contact with food. Official Journal of the European Union, 1-89. https://doi.org/10.3000/17252555.L_2011.012.eng

EC. (2020a). Database on food additives Accessed https://webgate.ec.europa.eu/foods system $/ \mathrm{main} /$ ?sector $=$ FAD\&auth $=$ SANCAS. (Accessed 21 June 2020).

EC. (2020b). Food contact materials Accessed https://webgate.ec.europa.eu/foods_syste $\mathrm{m} / \mathrm{main} /$ ? event=display. (Accessed 1 November 2020).

EFSA. (2012). Scientific opinion on the safety evaluation of the active substance iron (II) modified bentonite as oxygen absorber for use in active food contact materials. EFSA Journal, 10, 2906. https://doi.org/10.2903/j.efsa.2012.2906

EFSA. (2016a). Scientific opinion on the re-evaluation of silver (E 174) as food additive. EFSA Journal, 14, 4364. https://doi.org/10.2903/j.efsa.2016.4364

EFSA. (2016b). Scientific Opinion on the re-evaluation of gold (E 175) as a food additive. EFSA Journal, 14, 4362. https://doi.org/10.2903/j.efsa.2016.4362

FDA. (2020). Inventory of effective food contact substance (FCS) notifications Accessed https://www.accessdata.fda.gov/scripts/fdcc/?set=FCN. (Accessed 21 July 2020).

Foltynowicz, Z., Bardenshtein, A., Sängerlaub, S., Antvorskov, H., \& Kozak, W. (2017). Nanoscale, zero valent iron particles for application as oxygen scavenger in food packaging. Food Packaging and Shelf Life, 11, 74-83. https://doi.org/10.1016/j. fpsl.2017.01.003

Gaikwad, K. K., Singh, S., \& Lee, Y. S. (2018). Oxygen scavenging films in food packaging. Environmental Chemistry Letters, 16, 523-538. https://doi.org/10.1007/ s10311-018-0705-Z

Garcia, C. V., Shin, G. H., \& Kim, J. T. (2018). Metal oxide-based nanocomposites in food packaging: Applications, migration, and regulations. Trends in Food Science \& Technology, 82, 21-31. https://doi.org/10.1016/j.tifs.2018.09.021

Gautam, G., \& Mishra, P. (2017). Development and characterization of copper nanocomposite containing bilayer film for coconut oil packaging. Journal of Food Processing and Preservation, 41, Article e13243. https://doi.org/10.1111/jfpp.13243

Hardy, A., Benford, D., Halldorsson, T., Jeger, M. J., Knutsen, H. K., More, S., et al. (2018). Guidance on risk assessment of the application of nanoscience and nanotechnologies in the food and feed chain: Part 1, human and animal health. EFSA Journal, 16, Article e05327. https://doi.org/10.2903/j.efsa.2018.5327

He, X., Deng, H., \& Hwang, H.m. (2019). The current application of nanotechnology in food and agriculture. Journal of Food and Drug Analysis, 27, 1-21. https://doi.org/ 10.1016/j.jfda.2018.12.002

Hoseinnejad, M., Jafari, S. M., \& Katouzian, I. (2018). Inorganic and metal nanoparticles and their antimicrobial activity in food packaging applications. Critical Reviews in Microbiology, 44, 161-181. https://doi.org/10.1080/1040841X.2017.1332001

Hutter, S., Rüegg, N., \& Yildirim, S. (2016). Use of palladium based oxygen scavenger to prevent discoloration of ham. Food Packaging and Shelf Life, 8, 56-62. https://doi. org/10.1016/j.fpsl.2016.02.004

Jamróz, E., Kopel, P., Juszczak, L., Kawecka, A., Bytesnikova, Z., Milosavljevic, V., et al. (2019). Development of furcellaran-gelatin films with Se-AgNPs as an active packaging system for extension of mini kiwi shelf life. Food Packaging and Shelf Life, 21, 100339. https://doi.org/10.1016/j.fpsl.2019.100339

Jiang, Z. W., Yu, W. W., Li, Y., Zhu, L., \& Hu, C. Y. (2019). Migration of copper from nanocopper/polypropylene composite films and its functional property. Food Packaging and Shelf Life, 22, 100416. https://doi.org/10.1016/j.fpsl.2019.100416

Jo, Y., Garcia, C. V., Ko, S., Lee, W., Shin, G. H., Choi, J. C., et al. (2018) Characterization and antibacterial properties of nanosilver-applied polyethylene and polypropylene composite films for food packaging applications. Food Bioscience, 23, 83-90. https://doi.org/10.1016/j.fbio.2018.03.008

Kadam, D., Momin, B., Palamthodi, S., \& Lele, S. S. (2019). Physicochemical and functional properties of chitosan-based nano-composite films incorporated with biogenic silver nanoparticles. Carbohydrate Polymers, 211, 124-132. https://doi.org/ 10.1016/j.carbpol.2019.02.005

Khalaj, M. J., Ahmadi, H., Lesankhosh, R., \& Khalaj, G. (2016). Study of physical and mechanical properties of polypropylene nanocomposites for food packaging application: Nano-clay modified with iron nanoparticles. Trends in Food Science \& Technology, 51, 41-48. https://doi.org/10.1016/j.tifs.2016.03.007

Kostic, D., Vukasinovic-Sekulic, M., Armentano, I., Torre, L., \& Obradovic, B. (2019). Multifunctional ternary composite films based on PLA and Ag/alginate microbeads: Physical characterization and silver release kinetics. Materials Science and Engineering: C, 98, 1159-1168. https://doi.org/10.1016/j.msec.2019.01.074

Kumar, S., Shukla, A., Baul, P. P., Mitra, A., \& Halder, D. (2018). Biodegradable hybrid nanocomposites of chitosan/gelatin and silver nanoparticles for active food packaging applications. Food Packaging and Shelf Life, 16, 178-184. https://doi.org/ 10.1016/j.fpsl.2018.03.008

Lee, J. H., Jeong, D., \& Kanmani, P. (2019). Study on physical and mechanical properties of the biopolymer/silver based active nanocomposite films with antimicrobial activity. Carbohydrate Polymers, 224, 115159. https://doi.org/10.1016/j. carbpol.2019.115159

Lehner, M., Schlemmer, D., \& Sängerlaub, S. (2015). Recycling of blends made of polypropylene and an iron-based oxygen scavenger - influence of multiple extrusions on the polymer stability and the oxygen absorption capacity. Polymer Degradation and Stability, 122, 122-132. https://doi.org/10.1016/j. polymdegradstab.2015.10.020

Li, W., Li, L., Zhang, H., Yuan, M., \& Qin, Y. (2018). Evaluation of PLA nanocomposite films on physicochemical and microbiological properties of refrigerated cottage cheese. Journal of Food Processing and Preservation, 42, Article e13362. https://doi. org/10.1111/jfpp.13362

Liu, F., Hu, C. Y., Zhao, Q., Shi, Y. J., \& Zhong, H. N. (2016). Migration of copper from nanocopper/LDPE composite films. Food Additives \& Contaminants: Part A, 33, 1741-1749. https://doi.org/10.1080/19440049.2016.1237779

Li, L., Wang, Y., \& Zhu, Y. (2018). Facile preparation and good performance of nano-Ag/ metallocene polyethylene antibacterial coatings. Journal of Coatings Technology and Research, 15, 593-602. https://doi.org/10.1007/s11998-017-0019-2

Li, W., Zhang, C., Chi, H., Li, L., Lan, T., Han, P., et al. (2017). Development of antimicrobial packaging film made from poly(Lactic Acid) incorporating titanium dioxide and silver nanoparticles. Molecules, 22, 1170. https://doi.org/10.3390/ molecules 22071170

Li, L., Zhao, C., Zhang, Y., Yao, J., Yang, W., Hu, Q., et al. (2017). Effect of stable antimicrobial nano-silver packaging on inhibiting mildew and in storage of rice. Food Chemistry, 215, 477-482. https://doi.org/10.1016/j.foodchem.2016.08.013

Lomate, G. B., Dandi, B., \& Mishra, S. (2018). Development of antimicrobial LDPE/Cu nanocomposite food packaging film for extended shelf life of peda. Food Packaging and Shelf Life, 16, 211-219. https://doi.org/10.1016/j.fpsl.2018.04.001

Mackevica, A., Olsson, M. E., \& Hansen, S. F. (2016). Silver nanoparticle release from commercially available plastic food containers into food simulants. Journal of Nanoparticle Research, 18, 5. https://doi.org/10.1007/s11051-015-3313-x

Mathew, S., S, S., Mathew, J., \& Radhakrishnan, E. K. (2018). Poly(vinyl alcohol): Montmorillonite: Boiled rice water (starch) blend film reinforced with silver nanoparticles; characterization and antibacterial properties. Applied Clay Science, 161, 464-473. https://doi.org/10.1016/j.clay.2018.05.009

Mathew, S., S, S., Mathew, J., \& Radhakrishnan, E. K. (2019). Biodegradable and active nanocomposite pouches reinforced with silver nanoparticles for improved packaging of chicken sausages. Food Packaging and Shelf Life, 19, 155-166. https://doi.org/ 10.1016/j.fpsl.2018.12.009

Menezes, M. L. L. R., Pires, N. R., Cunha, P. L. R., Rosa, M. F., Souza, B. W. S., Feitosa, J. P. A., et al. (2019). Effect of tannic acid as crosslinking agent on fish skin gelatin-silver nanocomposite film. Food Packaging and Shelf Life, 19, 7-15. https:// doi.org/10.1016/j.fpsl.2018.11.005

Metak, A. M., Nabhani, F., \& Connolly, S. N. (2015). Migration of engineered nanoparticles from packaging into food products. Lebensmittel-Wissenschaft und -Technologie- Food Science and Technology, 64, 781-787. https://doi.org/10.1016/j. lwt.2015.06.001

Mousavi, F. P., Pour, H. H., Nasab, A. H., Rajabalipour, A. A., \& Barouni, M. (2015). Investigation into shelf life of fresh dates and pistachios in a package modified with nano-silver. Global Journal of Health Science, 8, 134-144. https://doi.org/10.5539/ gjhs.v8n5p134

Mu, H., Gao, H., Chen, H., Tao, F., Fang, X., \& Ge, L. (2013). A nanosised oxygen scavenger: Preparation and antioxidant application to roasted sunflower seeds and walnuts. Food Chemistry, 136, 245-250. https://doi.org/10.1016/j. foodchem.2012.07.121

Muthulakshmi, L., Rajini, N., Nellaiah, H., Kathiresan, T., Jawaid, M., \& Rajulu, A. V. (2017). Preparation and properties of cellulose nanocomposite films with in situ generated copper nanoparticles using Terminalia catappa leaf extract. International Journal of Biological Macromolecules, 95, 1064-1071. https://doi.org/10.1016/j. ijbiomac.2016.09.114

Nair, S. B., Alummoottil, N. J., \& Moothandasserry, S. S. (2017). Chitosan-konjac glucomannan-cassava starch-nanosilver composite films with moisture resistant and antimicrobial properties for food-packaging applications. Starch, 69, 1600210. https://doi.org/10.1002/star.201600210

Nasab, N. H., Jalili, M. M., \& Farrokhpay, S. (2018). Application of paraffin and silver coated titania nanoparticles in polyethylene nanocomposite food packaging films. Journal of Applied Polymer Science, 135, 45913. https://doi.org/10.1002/app.45913

Naskar, A., Khan, H., Sarkar, R., Kumar, S., Halder, D., \& Jana, S. (2018). Anti-biofilm activity and food packaging application of room temperature solution process based polyethylene glycol capped Ag-ZnO-graphene nanocomposite. Materials Science and Engineering: C, 91, 743-753. https://doi.org/10.1016/j.msec.2018.06.009

Ogunsona, E. O., Muthuraj, R., Ojogbo, E., Valerio, O., \& Mekonnen, T. H. (2020). Engineered nanomaterials for antimicrobial applications: A review. Applied Materials Today, 18, 100473. https://doi.org/10.1016/j.apmt.2019.100473

Oliani, W. L., Parra, D. F., Komatsu, L. G. H., Lincopan, N., Rangari, V. K., \& Lugao, A. B. (2017). Fabrication of polypropylene/silver nanocomposites for biocidal applications. Materials Science and Engineering: C, 75, 845-853. https://doi.org/ 10.1016/j.msec.2017.02.109

Orsuwan, A., Shankar, S., Wang, L. F., Sothornvit, R., \& Rhim, J. W. (2016). Preparation of antimicrobial agar/banana powder blend films reinforced with silver nanoparticles. Food Hydrocolloids, 60, 476-485. https://doi.org/10.1016/j. foodhyd.2016.04.017 
Ortega, F., García, M. A., \& Arce, V. B. (2019). Nanocomposite films with silver nanoparticles synthesized in situ: Effect of corn starch content. Food Hydrocolloids, 97, 105200. https://doi.org/10.1016/j.foodhyd.2019.105200

Pagno, C. H., Costa, T. M. H., Menezes, E. W., Benvenutti, E. V., Hertz, P. F., Matte, C. R., et al. (2015). Development of active biofilms of quinoa (Chenopodium quinoa W.) starch containing gold nanoparticles and evaluation of antimicrobial activity. Food Chemistry, 173, 755-762. https://doi.org/10.1016/j.foodchem.2014.10.068

Palza, H., Galarce, N., Bejarano, J., Beltran, M., \& Caviedes, P. (2017). Effect of copper nanoparticles on the cell viability of polymer composites. International Journal of Polymeric Materials and Polymeric Biomaterials, 66, 462-468. https://doi.org/ 10.1080/00914037.2016.1252343

Palza, H., Quijada, R., \& Delgado, K. (2015). Antimicrobial polymer composites with copper micro- and nanoparticles: Effect of particle size and polymer matrix. Journal of Bioactive and Compatible Polymers, 30, 366-380. https://doi.org/10.1177/ 0883911515578870

Pourzahedi, L., Vance, M., \& Eckelman, M. J. (2017). Life cycle assessment and release studies for 15 nanosilver-enabled consumer products: Investigating hotspots and patterns of contribution. Environmental Science \& Technology, 51, 7148-7158. https://doi.org/10.1021/acs.est.6b05923

Qin, Y., Liu, Y., Yuan, L., Yong, H., \& Liu, J. (2019). Preparation and characterization of antioxidant, antimicrobial and $\mathrm{pH}$-sensitive films based on chitosan, silver nanoparticles and purple corn extract. Food Hydrocolloids, 96, 102-111. https://doi. org/10.1016/j.foodhyd.2019.05.017

Realini, C. E., \& Marcos, B. (2014). Active and intelligent packaging systems for a modern society. Meat Science, 98, 404-419. https://doi.org/10.1016/j. meatsci.2014.06.031

Salari, M., Khiabani, M. S., Mokarram, R. R., Ghanbarzadeh, B., \& Kafil, H. S. (2018). Development and evaluation of chitosan based active nanocomposite films containing bacterial cellulose nanocrystals and silver nanoparticles. Food Hydrocolloids, 84, 414-423. https://doi.org/10.1016/j.foodhyd.2018.05.037

Santos, C. A., Ingle, A. P., \& Rai, M. (2020). The emerging role of metallic nanoparticles in food. Applied Microbiology and Biotechnology, 104, 2373-2383. https://doi.org/ 10.1007/s00253-020-10372-X

Sarwar, M. S., Niazi, M. B. K., Jahan, Z., Ahmad, T., \& Hussain, A. (2018). Preparation and characterization of PVA/nanocellulose/Ag nanocomposite films for antimicrobial food packaging. Carbohydrate Polymers, 184, 453-464. https://doi. org/10.1016/j.carbpol.2017.12.068

Shankar, S., \& Rhim, J. W. (2015). Amino acid mediated synthesis of silver nanoparticles and preparation of antimicrobial agar/silver nanoparticles composite films. Carbohydrate Polymers, 130, 353-363. https://doi.org/10.1016/j. carbpol.2015.05.018

Shankar, S., \& Rhim, J. W. (2016). Tocopherol-mediated synthesis of silver nanoparticles and preparation of antimicrobial PBAT/silver nanoparticles composite films. Lebensmittel-Wissenschaft und -Technologie- Food Science and Technology, 72, 149-156. https://doi.org/10.1016/j.lwt.2016.04.054

Shankar, S., \& Rhim, J. W. (2017). Preparation and characterization of agar/lignin/silver nanoparticles composite films with ultraviolet light barrier and antibacterial properties. Food Hydrocolloids, 71, 76-84. https://doi.org/10.1016/j. foodhyd.2017.05.002

Shankar, S., Rhim, J. W., \& Won, K. (2018). Preparation of poly(lactide)/lignin/silver nanoparticles composite films with UV light barrier and antibacterial properties. International Journal of Biological Macromolecules, 107, 1724-1731. https://doi.org/ 10.1016/j.ijbiomac.2017.10.038
Tamayo, L., Azócar, M., Kogan, M., Riveros, A., \& Páez, M. (2016). Copper-polymer nanocomposites: An excellent and cost-effective biocide for use on antibacterial surfaces. Materials Science and Engineering: C, 69, 1391-1409. https://doi.org/ 10.1016/j.msec.2016.08.041

Tang, S., Wang, Z., Li, P., Li, W., Li, C., Wang, Y., et al. (2018). Degradable and photocatalytic antibacterial Au-TiO2/sodium alginate nanocomposite films for active food packaging. Nanomaterials, 8, 930. https://doi.org/10.3390/ nano8110930

Tavakoli, H., Rastegar, H., Taherian, M., Samadi, M., \& Rostami, H. (2017). The effect of nano-silver packaging in increasing the shelf life of nuts: An in vitro model. Italian Journal of Food Safety, 6, 6874. https://doi.org/10.4081/ijfs.2017.6874

Tiimob, B. J., Mwinyelle, G., Abdela, W., Samuel, T., Jeelani, S., \& Rangari, V. K. (2017). Nanoengineered eggshell-silver tailored copolyester polymer blend film with antimicrobial properties. Journal of Agricultural and Food Chemistry, 65, 1967-1976. https://doi.org/10.1021/acs.jafc.7b00133

Vasile, C., Rapa, M., Stefan, M., Stan, M., Macavei, S., Darie-Nita, R. N., et al. (2017). New PLA/ZnO:Cu/Ag bionanocomposites for food packaging. Express Polymer Letters, 11, 531-544. https://doi.org/10.3144/expresspolymlett.2017.51

Vera, P., Echegoyen, Y., Canellas, E., Nerín, C., Palomo, M., Madrid, Y., et al. (2016). Nano selenium as antioxidant agent in a multilayer food packaging material. Analytical and Bioanalytical Chemistry, 408, 6659-6670. https://doi.org/10.1007/ s00216-016-9780-9

Vishnuvarthanan, M., \& Rajeswari, N. (2019). Food packaging: pectin-laponite-Ag nanoparticle bionanocomposite coated on polypropylene shows low $\mathrm{O} 2$ transmission, low Ag migration and high antimicrobial activity. Environmental Chemistry Letters, 17, 439-445. https://doi.org/10.1007/s10311-018-0770-3

Wang, W., Yu, Z., Alsammarraie, F. K., Kong, F., Lin, M., \& Mustapha, A. (2020). Properties and antimicrobial activity of polyvinyl alcohol-modified bacterial nanocellulose packaging films incorporated with silver nanoparticles. Food Hydrocolloids, 100, 105411. https://doi.org/10.1016/j.foodhyd.2019.105411

Weiner, R. G., Sharma, A., Xu, H., Gray, P. J., \& Duncan, T. V. (2018). Assessment of mass transfer from poly(ethylene) nanocomposites containing noble-metal nanoparticles: A systematic study of embedded particle stability. ACS Applied Nano Materials, 1, 5188-5196. https://doi.org/10.1021/acsanm.8b01241

Westerband, E. I., \& Hicks, A. L. (2018a). Life cycle impact of nanosilver polymer-food storage containers as a case study informed by literature review. Environmental Sciences: Nano, 5, 933-945. https://doi.org/10.1039/C7EN01043E

Westerband, E. I., \& Hicks, A. L. (2018b). Nanosilver-enabled food storage container tradeoffs: Environmental impacts versus food savings benefit, informed by literature. Integrated Environmental Assessment and Management, 14, 769-776. https://doi.org/ 10.1002/ieam. 4093

Wu, Z., Huang, X., Li, Y.-C., Xiao, H., \& Wang, X. (2018). Novel chitosan films with laponite immobilized Ag nanoparticles for active food packaging. Carbohydrate Polymers, 199, 210-218. https://doi.org/10.1016/j.carbpol.2018.07.030

Yu, H.-Y., Yang, X.-Y., Lu, F.-F., Chen, G.-Y., \& Yao, J.-M. (2016). Fabrication of multifunctional cellulose nanocrystals/poly(lactic acid) nanocomposites with silver nanoparticles by spraying method. Carbohydrate Polymers, 140, 209-219. https:// doi.org/10.1016/j.carbpol.2015.12.030

Zhai, X., Li, Z., Shi, J., Huang, X., Sun, Z., Zhang, D., et al. (2019). A colorimetric hydrogen sulfide sensor based on gellan gum-silver nanoparticles bionanocomposite for monitoring of meat spoilage in intelligent packaging. Food Chemistry, 290, 135-143. https://doi.org/10.1016/j.foodchem.2019.03.138 